OCCASIONAL PAPER

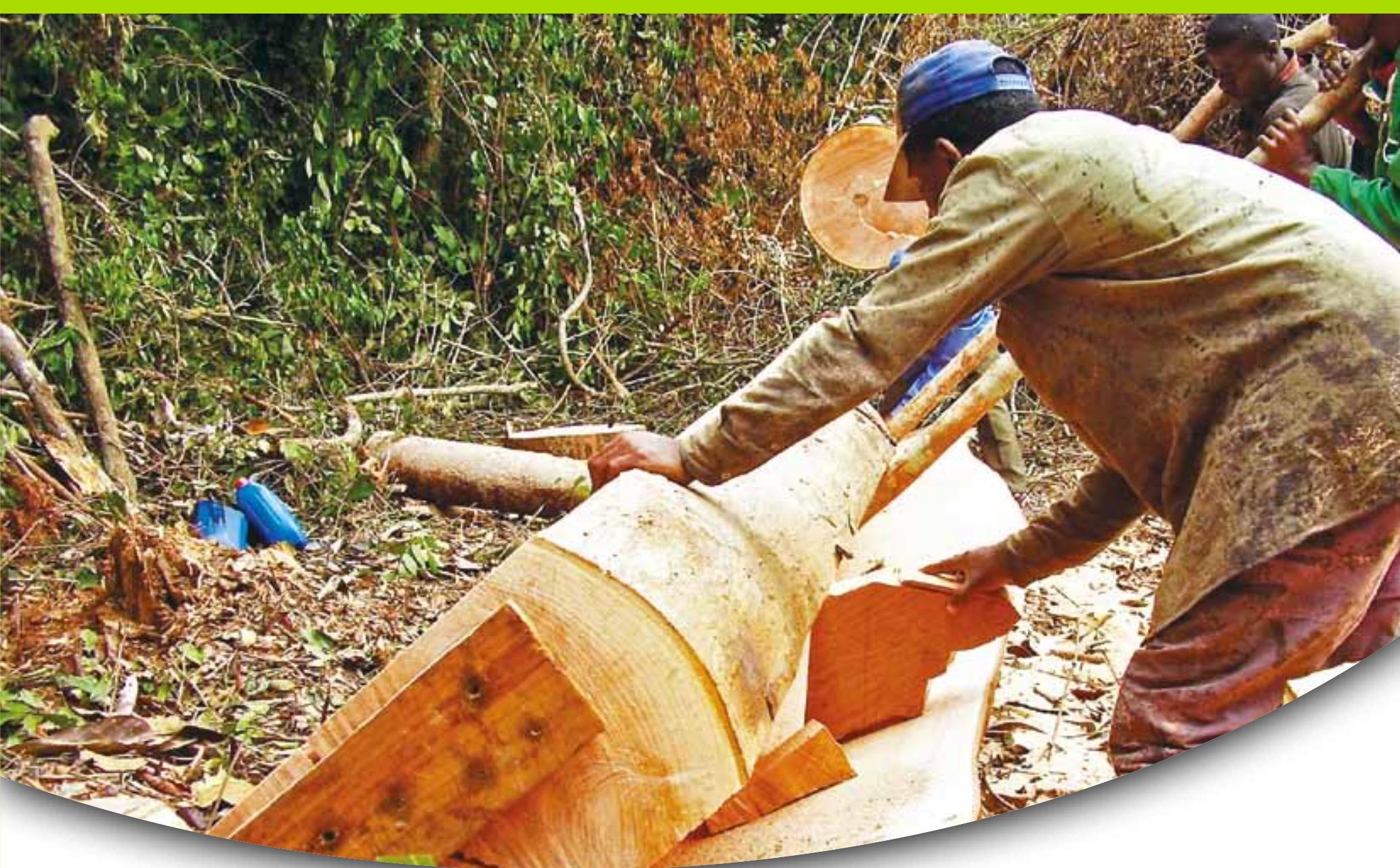

The domestic market for small-scale chainsaw milling in the Republic of Congo Present situation, opportunities and challenges

Guillaume Lescuyer

Régis Is-maël Yembe-Yembe

Paolo Omar Cerutti
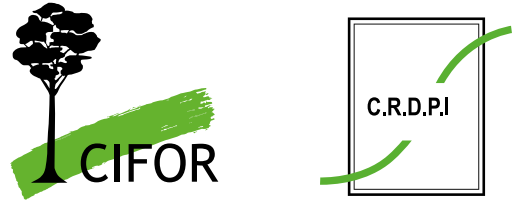



\title{
The domestic market for small-scale chainsaw milling in the Republic of Congo \\ Present situation, opportunities and challenges
}

\author{
Guillaume Lescuyer \\ CIFOR and International Center of Agricultural Research for Development (CIRAD) \\ Régis Is-maël Yembe-Yembe \\ Centre de recherche sur la durabilité et la productivité des plantations industrielles (CRDPI) \\ Paolo Omar Cerutti \\ CIFOR and Australian National University (ANU)
}


Occasional Paper 74

(c) 2011 Center for International Forestry Research All rights reserved

ISBN 978-602-8693-76-9

Lescuyer, G., Yembe-Yembe, R. I. and Cerutti, P. O. 2011. The domestic market for small-scale chainsaw milling in the Republic of Congo: Present situation, opportunities and challenges. Occasional Paper 74. CIFOR, Bogor, Indonesia.

Cover photo : Régis Is-maël Yembe-Yembe

CIFOR

Jl. CIFOR, Situ Gede

Bogor Barat 16115

Indonesia

$\mathrm{T}+62(251) 8622-622$

$\mathrm{F}+62$ (251) 8622-100

E cifor@cgiar.org

www.cifor.org

This document has been produced with the financial assistance of the European Union and with the technical support of IFAD. The views expressed herein can in no way be taken to reflect the official opinion of IFAD and the European Union. 


\section{Table of contents}

$\begin{array}{ll}\text { Abbreviations } & \mathbf{v}\end{array}$

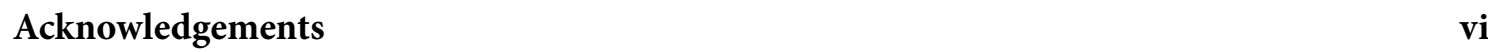

$\begin{array}{ll}\text { Executive summary } & \text { vii }\end{array}$

$\begin{array}{ll}\text { Foreword } & \text { ix }\end{array}$

1 Introduction $\quad 1$

2 Forestry legislation $\quad \mathbf{5}$

$\begin{array}{lr}\text { Interviews with sawyers } & 7\end{array}$

3 Survey and analytical methods $\quad 7$

$\begin{array}{lr}\text { Monitoring flows of chainsaw timber into Brazzaville } & 8\end{array}$

$\begin{array}{lr}\text { Monitoring outlets in Pointe-Noire } & 9\end{array}$

Upstream: Economic importance of the chainsaw timber sector in rural areas 13

4 Results $\quad 13$

$\begin{array}{ll}\text { Consumption of chainsaw timber in Brazzaville } & 17\end{array}$

$\begin{array}{lr}\text { Sales and consumption of chainsaw products in Pointe-Noire } & 19\end{array}$

Macro-economic importance of small-scale chainsaw milling sector 23

5 Discussion and conclusion $\quad 23$

$\begin{array}{ll}\text { Rethinking the regulations } & 25\end{array}$

$\begin{array}{ll}\text { Incentives to improve governance } & 27\end{array}$

6 References $r$ 


\section{List of figures, tables, boxes and maps}

\section{Figures}

1 Years when the 62 surveyed chainsaw millers entered the profession 13

2 A gruminette for small-scale sawing $\quad 15$

3 Breakdown of expenses for small-scale timber production in rural areas 16

4 Estimates of weekly sales of sawnwood in Brazzaville 18

5 Sawnwood deliveries to Brazzaville, per entry point 18

6 Types of timber products entering Brazzaville 19

7 Estimate of weekly consumption of sawnwood in Pointe-Noire 20

8 Types of sawn products and species exploited around Pointe-Noire 21

\section{Tables}

1 Characteristics distinguishing the domestic and industrial sectors ix

2 Survey schedule in Brazzaville 9

3 Small-scale timber markets in Pointe-Noire $\quad 10$

4 Chainsaw millers' perceptions of problems encountered in their work (multiple choice) 14

5 Profits and costs for chainsaw timber in rural areas (CFA FRANCS $/ \mathrm{m}^{3}$ of sawnwood) 15

6 Intensity and location of small-scale chainsaw milling operations $\quad 17$

7 Annual volumes of chainsaw timber in Congo 23

\section{Box}

1 Voluntary Partnership Agreement in Republic of Congo

\section{Maps}

1 Location of study sites 7

2 Location of monitoring points for timber entering Brazzaville $\quad 8$

3 Location of small-scale timber markets in Pointe-Noire 11 


\section{Abbreviations}

$\begin{array}{ll}\text { CIFOR } & \text { Center for International Forestry Research } \\ \text { CRDPI } & \text { Centre de recherche sur la durabilité et la productivité des plantations industrielles } \\ \text { FLEGT } & \text { Forest Law Enforcement, Governance and Trade } \\ \text { FSC } & \text { Forest Stewardship Council } \\ \text { NPFE } & \text { Non-Permanent Forest Estate } \\ \text { OFAC } & \text { Observatory for the Forests of Central Africa } \\ \text { PFE } & \text { Permanent Forest Estate } \\ \text { VPA } & \text { Voluntary Partnership Agreement }\end{array}$




\section{Acknowledgements}

\author{
A large part of the data in Brazzaville was collected \\ by Marion Loemba under especially difficult \\ conditions. Collaborative relationships were \\ developed with many people in the forestry services \\ and with resource persons in both cities and rural \\ areas. Thanks to their assistance, our research \\ progressed smoothly.
}

The first research findings were presented and discussed at a workshop on wood processing in the Republic of Congo, organised by IFIA-ITTOFAO in Brazzaville in March 2011. Thereafter, the preliminary version of this report was sent to several of the workshop participants for comment. We especially thank Alain Noël Ampolo, AlainMarius Ngoya Kessy, Domenico Giostra, Marien N'gouabi, Alain Pénelon, André Ondele-Kanga,
Rosalie Matondo, Andrew Wardell, Simon Makanga, Séraphin Dzomambou, Eric Forni and an anonymous reader whose suggestions and questions contributed to the improvement of this document.

This study was funded through the FORAF project entitled 'Observatoire des forêts d'Afrique centrale' and was finalised as part of the PRO-Formal project 'Policy and regulatory options recognising and better integrating the domestic timber sector in tropical countries in the formal economy'. Both projects were funded by the European Union. The views expressed in this document, however, do not in any way reflect the official position of the European Union or CIFOR. 


\section{Executive summary}

In 2000, the Republic of Congo adopted a new forestry law that emphasised export-oriented, large-scale industrial forestry. Timber from smallscale logging operations for the domestic market were ignored, not recorded in official statistics and generally produced without a valid permit. Congo in 2009 initialled and in 2010 signed a Voluntary Partnership Agreement (VPA) with the European Commission, promising a legal framework for all national timber production by 2013. Preparations for the implementation of the VPA are well underway for the forest concessions, especially in the northern part of the country, but the domestic timber sector has been largely ignored in this process. This report presents a quantitative and qualitative evaluation of the country's domestic timber market as a step towards identifying options for legalising the market and ensuring its sustainability.

Estimates are based on uninterrupted monitoring of sawnwood entering Brazzaville between August 2008 and November 2009, on sawnwood sales in Pointe-Noire markets between February and November 2009 and on interviews with 62 smallscale chainsaw millers in four supply zones. Overall estimates of annual sawnwood sales and consumption are summarised in the table below.

Excluding industrial timber products sold in the domestic market, in 2009, the volume of informal timber production exceeded that of Congolese sawnwood exports, despite the crisis in the forest industry that saw exports falling twice as low as the national average for the five preceding years. This subsector is a source of employment for many people, creating at least 600 permanent jobs and 300 temporary jobs in the two cities studied. In rural areas, informal chainsaw milling creates the equivalent of at least 2000 jobs. The estimate for the industrial sector is far higher, somewhere around 7500 jobs.

Chainsaw milling is a major economic activity that generates annual sales of close to 15 billion CFA Francs, a fifth of which enters rural economies as revenue from the sale of trees by customary owners and from wages paid to workers (33000 CFA Francs per cubic metre of sawn timber). Officials in decentralised government agencies also benefit from this activity, given that 'parafiscal' charges make up close to $18 \%$ of the cost price of informal timber production in rural areas, or about 12000 CFA Francs $/ \mathrm{m}^{3}$. In total, close to 1.2 billion CFA Francs is levied unduly each year by individual representatives of certain decentralised state services.

Those operating in the small-scale chainsaw milling sector experience a range of problems and threats. First, current operating methods jeopardise forest sustainability as loggers have to trek long distances to locate trees, and most of those they fell have a small diameter. Brazzaville markets generally offer 'red woods', usually transported via the Congo River, whereas the Pointe-Noire markets favour

\begin{tabular}{lcr}
\hline Annual estimate (2009) & Brazzaville $\left(\mathrm{m}^{3}\right)$ & Pointe-Noire $\left(\mathrm{m}^{3}\right)$ \\
\hline Annual volumes of timber entering the city include: & 34500 & \\
- industrial products & 8500 & \\
- informal sector timber & 26000 & 98000 \\
Annual volumes of timber sold in the city include: & & 23000 \\
- 'double sales' & & 2000 \\
- industrial products & & 73000 \\
- informal sawmill products & 99000 \\
\hline Total annual volume of informal sector timber & \\
\hline
\end{tabular}


okoumé (Aucoumea klaineana), mainly used for formwork.

Second, the current forest regulations - mainly operating through the special permit - do little to encourage informal small-scale sawyers to seek legal status. Rather, these sawyers would be more inclined to adopt legal practices if the legal requirements were adapted and/or revised. Facilitated access to legal logging authorisations should be accompanied by technical, financial and institutional measures that help small-scale chainsaw millers become more professional.

Last, better governance is an important prerequisite for effective application of new forestry-related regulations. It should be underpinned by unambiguous actions to fight corruption, along with economic incentives for the government services responsible for the application and control of the legalised chainsaw milling sector. 


\section{Foreword}

Since early 2008, the Center for International Forestry Research (CIFOR) has been researching the domestic timber sector in Cameroon, Gabon (Libreville), Republic of Congo (Brazzaville, Pointe-Noire), Democratic Republic of Congo (Kinshasa) and Central African Republic (Bangui) in collaboration with partners based in these countries. Funding to conduct research at the sub-regional level was obtained mainly from the Netherlands Directorate-General for International Cooperation (DGIS), the European Union and the French Development Agency.

We decided to conduct parallel research on the domestic timber sector in several countries in the Congo Basin for a variety of reasons. First, there is very little information available on this sector, which is still largely informal, despite growing demand for its products in urban areas. In all the countries, this sector accounts for a sizeable share of the timber production, sometimes even more than the official sector. Second, all five countries have joined the European Union in adopting the FLEGT-VPA process, which imposes a short- or medium-term obligation to ensure the traceability and legality of all products from forest operations, whether for the national market or for export. Last, these countries have similar forestry codes and policies, and the local populations use the lands and the forestry resources in a similar manner, thus giving relevance to comparisons of how small-scale sawmills operate and capitalise their products, comparisons that can be used to analyse the sector at the sub-regional level.

What is meant by 'domestic timber sector'? Does it mean the opposite of the industrial sector that fells trees and processes the timber for export? Although the industrial sector and domestic consumption are connected - some of the industrial scrap is sold on the national market - the domestic sector is different as it only targets national demand or informal exports to neighbouring countries (Table 1).

The whole domestic timber sector is marked by informal practices, from felling trees to selling sawnwood to the final consumer. Although the informal methods do not quite respect all the national regulations, they do not necessarily break the law either. That is why we prefer the word 'informal' to 'illegal'. The activities of most of the loggers could easily be covered by a legal felling permit but, for various reasons that we will try to

Table 1. Characteristics distinguishing the domestic and industrial sectors

\begin{tabular}{|c|c|c|}
\hline & Domestic & Industrial \\
\hline Felling permit & No (or very rarely) & $\begin{array}{l}\text { Yes (concessions, community } \\
\text { forests, recovery, etc.) }\end{array}$ \\
\hline $\begin{array}{l}\text { Felling and processing techniques } \\
\text { (Techniques d'abattage et de } \\
\text { transformation) }\end{array}$ & $\begin{array}{l}\text { Chainsaw for felling and processing } \\
\text { (sometimes portable saw) } \\
\text { Small number of trees per operation }\end{array}$ & $\begin{array}{l}\text { Heavy machinery, often in the } \\
\text { surface area allocation (assiettes } \\
\text { annuelles de coupe) } \\
\text { Large number of trees per operation } \\
\text { Processing plants }\end{array}$ \\
\hline Sales & $\begin{array}{l}\text { Lower-quality sawnwood for } \\
\text { national market and neighbouring } \\
\text { countries }\end{array}$ & $\begin{array}{l}\text { Logs, sawn timber, veneer, plywood, } \\
\text { wooden floors, almost exclusively } \\
\text { for export }\end{array}$ \\
\hline Taxes and regulations & Largely informal & Largely formal \\
\hline
\end{tabular}


explain, the loggers prefer their informal economy. The main purpose of this report, therefore, is to explain the functioning of the domestic timber sector in an effort to contribute to finding ways to make it legal and secure.

In response to this situation, CIFOR is publishing four reports in 2011 and 2012 describing the domestic timber sector in Cameroon, Gabon,
Republic of Congo and Central African Republic, as well as a final report to compare the operating methods and challenges of the domestic sawmill sector throughout the sub-region. We hope that this research will contribute to improving forestry policies at the national and sub-regional levels by giving this activity, undervalued and all too often criminalised, the position it deserves. 


\section{Introduction}

$\mathrm{T}$ The Republic of Congo has about 18.5 million ha of dense forestland and about 8.4 million ha of other forest areas, composed of forest-savannah mosaics, forest-crop and deciduous forest mosaics (Bayol and Eba'a Atyi 2009). These forests are found in three main areas: the North Congo Massif and, in southern Congo, the Chaillu Massif and the Mayombe Massif (Mertens et al. 2007). These forests contribute substantially to the livelihoods of rural populations and, for the past century, have contributed to the country's macroeconomic development through their timber operations. Timber production has grown since the 1990s with the arrival of many new economic operators, and especially since the introduction of the 2000 Forestry Code (Cerutti et al. 2010). In 2006, the forestry sector accounted for 5.6\% of GDP (Bayol and Eba'a Atyi 2009) ${ }^{1}$ and timber exports are second only to oil as a source of export revenue, reaching close to 10 million euros in 2008. In 2009 - a crisis year in this sector - Congo exported $546000 \mathrm{~m}^{3}$ of timber as logs mainly to China, $93000 \mathrm{~m}^{3}$ of sawnwood, about $20000 \mathrm{~m}^{3}$ of veneer and plywood and $354000 \mathrm{~m}^{3}$ of eucalyptus logs and woodchips. Although Article 180 of the Forestry Code requires operators to process $85 \%$ of their wood in the country, timber from natural forests is usually exported as logs, although efforts have been made during the past decade to reverse this trend.

1 When the source is not specified, the figures were obtained from the website of the Observatory for the Forests of Central Africa (OFAC): http://www.observatoire-comifac.net
According to the Observatory for the Forests of Central Africa (OFAC), timber produced in the formal sector generates close to 7500 direct jobs and twice as many indirect jobs, i.e. about $10 \%$ of official employment in Congo.

The sustainable forest management model for Congo is similar to that of the other countries in the sub-region: forest concessions operate according to a management plan to organise industrial timber production essentially for export. In 2008, more than 15 million ha of the 22.5 million ha of forestland in the permanent forest estate was classified as production forest. That same year, the state services approved three management plans, and another 22 were in the preparation or adoption phase to cover an area of about 8.4 million ha.

The forests with the longest felling history because of their easy access - are located in the Mayombe and Chaillu Massifs (Barbier 2004). The two most prized species in these forests are okoumé (Aucoumea klaineana) and limba (Terminalia superba). In 1990 , more than $50 \%$ of the total national production came from these two forests; by 2010 , this figure had dropped to about $30 \%$. At present, most of the industrial timber comes from large forest concessions in northern Congo, four of which have Forest Stewardship Council (FSC) sustainable management certification. The two most prized species in these forests are sapelli (Entandrophragma cylindricum) and sipo (Entandrophragma utile). 
In 2010, the Republic of Congo pledged to improve its forestry sector by concluding a Voluntary Partnership Agreement (VPA) with the European Union (Box 1).

The VPA is meant to improve the sustainability of forest management, regardless of whether the output is intended for export or for the national market (Cerutti et al. 2010). However, very little information is available on domestic demand for timber products, especially sawnwood. Although the regulations theoretically oblige logging companies to transform $85 \%$ of their felled trees within the country, nearly all sawnwood from the industrial sector is intended for the export market, which offers higher prices. Recently, a few companies have been trying to penetrate the domestic market with lower-quality sawnwood and sawmill scrap, but these activities are still marginal. Hence, the informal sector meets most of the domestic demand for sawnwood. The Forestry Code has provisions for such milling but the operators seldom apply for the 'small permits' and procedures set by the Ministry of Sustainable Development, Forest Economy and the Environment (hereafter Ministry of Forest Economy) make such permits difficult to obtain.

The informal sector in developing countries can be defined in terms of its particular type of social dynamism (Ngouari 2005). People in this economic sector are often acting out of a sense of survival and are resourceful in carrying out economic activities that are not registered with the state. In the main cities, nearly all the furniture is made by artisans who use timber recovered from industry - generally without guarantees of origin - or obtained from informal small-scale sources. The informality of small-scale chainsaw enterprises is not unusual in Congo; according to Maldonado and Gaufryau (2001), the informal sector accounted for approximately $50 \%$ of the jobs in the country in 2000.

The informal sector is not reported in national and international statistics and is not officially monitored by the regional offices of the Ministry of Forest Economy. Small-scale logging operations, both formal and informal, should receive greater attention, for the following reasons. First, the sector plays a direct role in the country's economic development both by contributing to vital sectors such as construction and by creating rural and urban jobs. Second, by concluding a VPA, the Congolese government promised to ensure that all wood production from the forests would be monitored and legal, whether for export or for national consumption. By breaking this agreement, the country will be challenging the VPA itself and, thereby, jeopardising its guaranteed access to European markets.

\section{Box 1. Voluntary Partnership Agreement in Republic of Congo (excerpt from EFI 2010)}

On 17 May 2010, the government of the Republic of Congo and the European Union signed a Voluntary Partnership Agreement (VPA) on Forest Law Enforcement, Governance and Trade (FLEGT). The purpose of the VPA is to provide the necessary regulatory framework, systems, controls and verification procedures to ensure that all timber exports from Congo to the EU have been legally acquired, harvested, processed, transported and exported.

The VPA relies on the efforts of both parties to promote the sustainable management of all Congolese forests. The Republic of Congo pledges to apply the legality assurance system described in this agreement not only to exports destined to the EU but also to all sources of commercial timber and derived products that are produced, processed and/or acquired in Congo, including those for export to countries not in the EU, all timber sold on the national market, imported timber and timber in transit.

The FLEGT authorisation system is scheduled to enter into force in 2013 when the legality assurance system has been established and is fully operational. Congo will then be able to issue FLEGT authorisations attesting to the legality of all shipments of timber and derived products to the EU. 
This report uses information on small-scale timber operations in Brazzaville and Pointe-Noire, gathered between April 2008 and November 2009 , to add quantitative and qualitative data to preparations for a legal framework and guarantees for Congo's informal timber sector. After summarising the forestry regulations that are used to demarcate small-scale timber operations, the report describes the survey methods. The results are presented in the third part, with an emphasis on the upstream and downstream phases of informal production. The report ends with a discussion of possible options for formalising the small-scale chainsaw milling sector in the Republic of Congo and ensuring its sustainability. 



\section{Forestry legislation}

S mall-scale chainsaw milling began in the Republic of Congo in the 1930s to provide wood to make sleepers for the Congo-Ocean railway; in the 1940s, it provided a source of energy for the Compagnie française du Haut et Bas Congo (Ondele-Kanga 2011). In 1974, in an attempt to increase the economic value of the small-scale timber industry, Congolese lawmakers identified three types of felling permits that could be issued to national operators: (1) special permit, designed to meet domestic demand; (2) the commercial timber permit, which authorised the felling of about 500 trees; and (3) the temporary logging permit, which covered a specific land area for up to seven years. These permits were defined in Law No. 004 of 4 January 1974 establishing the Forestry Code, and then reiterated in Law No. 032 of 7 July 1982 amending certain provisions of the 1974 law. The one-year commercial timber permit and the seven-year temporary logging permit authorised the state forestry services to control forest worksites managed by national operators (Ondele-Kanga 2011). Law No. 16-2000 of 20 November 2000 enacting the Forestry Code replaced these two permits with a revised version of the special permit.

In addition, the current Forestry Code defines the state forest estate, dividing it into the permanent forest estate (PFE) and the non-permanent forest estate (NPFE). The PFE is designated for forest and wildlife habitats, and includes forest management units, which produce timber according to a management plan. The NPFE is composed of protected forestland that has not been classified and is the public estate of the state.
The Forestry Code recognises customary user rights, which apply to all forests, but the management plan may limit these rights in PFE forests. Article 42 of the Forestry Code stipulates that 'user rights are meant only to satisfy the personal needs of the users'; that is, users cannot exercise these rights for commercial purposes.

Under Article 63 of the Forestry Code, forest products from the public estate intended for commercial purposes - including products that have been part of traditional activities long established by local communities - may be used only by a stateowned company (en régie) or by the holder of a felling permit issued by the government forests services. The available felling permits are: (1) industrial processing agreements; (2) management and processing agreements; (3) plantation logging permits; and (4) special permits.

Although the special permit generally applies for nontimber forest products, in exceptional cases, it may be used for woody plants (Bayol and Eba'a Atyi 2009). The special permit for timber operations allows felling of up to five trees for commercial purposes and three trees for domestic consumption. It is issued only in areas where resident populations have difficulty in obtaining processed wood, and the products may only be sold locally within the local zone. The permit is issued exclusively to Congolese nationals and to non-governmental organisations and associations governed by Congolese law. It is valid for one month and cannot be extended, and a permit holder may not hold more than one valid permit. 
To be eligible for a special permit for timber production, the applicant must have a professional licence (agrément à la profession), as indicated in Decree No. 2002-437 of 31 December 2002, which sets out the conditions for forest management and use, and in Order No. 2930 of 31 March 2004, which lists the costs of issuing the professional licence and the professional card for small-scale forestry and wood production activities. After receiving a professional licence, the operator can send an application to the Forestry Economy Team (brigade de l'économie forestière) to be forwarded to the regional government office, accompanied by a payment calculated based on the forest tax. The regional government office, upon receipt of the application, instructs the team to hammermark the harvestable trees in the zone covered by the permit. The government office authorises the special permit after receiving the hammer-marking report and issues it upon receipt of the forest tax. After felling and processing a tree, the logger must then apply to the government forestry services for another authorisation (theoretically free of charge) to transport the products to the regional markets. As this process suggests, obtaining the special permit for small-scale operations is costly and time-consuming, and the permit, once finally received, is valid for only a short period.

In both Brazzaville and Pointe-Noire, the regional office of the Ministry of Forest Economy works with checkpoints located at city entrances and with mobile brigades to verify the validity of documents authorising the exploitation and transport of forest products. In addition to permanent checkpoints, patrols inspect forest products in the area around Brazzaville.

The decentralised forestry services have a certain logistical capacity to enforce regulations, especially regulations regarding small-scale logging. However, local economic, political and economic dynamics make it difficult for the decentralised agents to apply the regulations effectively - a situation that encourages the development of the informal sector. Small-scale chainsaw milling, which meets a strong urban demand for which there is no expected replacement in the short-term future, is a good example of how this phenomenon operates in practice. The related dynamics are analysed in detail in the results section. 


\section{Survey and analytical methods}

$\mathrm{W}$ e carried out three types of survey to investigate the small-scale chainsaw milling sector in Brazzaville and Pointe-Noire: (1) interviews with sawyers who supply the urban markets in these two cities; (2) monitoring of deliveries from small-scale sawmills in Brazzaville; and (3) monitoring of sales in timber outlets in Pointe-Noire. Different approaches were used in the two cities because of differences in delivery methods. The methods for each survey type are described below.

\section{Interviews with sawyers}

By monitoring the flows and sales of chainsaw timber in Pointe-Noire and Brazzaville, we obtained information on the main sources of supply. This information was cross-checked and confirmed based on other sources of information, such as discussions with senior staff at the Ministry of Forest Economy and desk studies (Ampolo 2005, Nkoua et al. 2009). Four villages were selected to study the upstream side of the

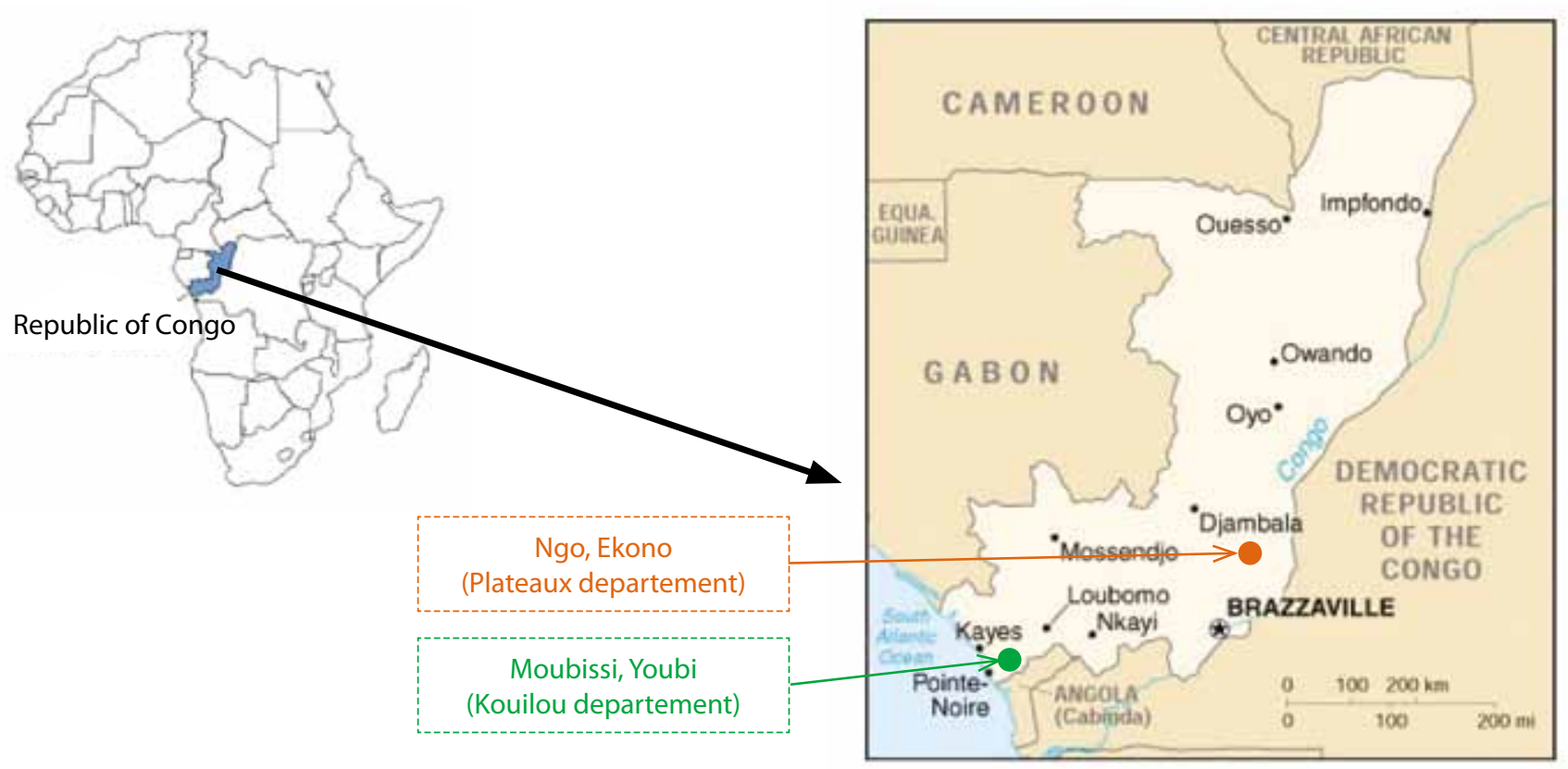

Map 1. Location of study sites 
sector and to interview sawyers at their felling sites: Ekono and Ngo in the Plateaux District for Brazzaville (Ampolo 2005) and Mboubissi and Youbi for Pointe-Noire (Map 1). Data from these four villages, which supply sawn timber to the Brazzaville and Pointe-Noire markets, contributed to understanding sawyers' operating methods in the areas surrounding the two target cities.

Interviews were held with 62 sawyers (43 near Pointe-Noire and 19 near Brazzaville) between August 2008 and December 2009. The semistructured interview grid used in these surveys was the same as that used in Cameroon, Gabon, Central African Republic and Democratic Republic of Congo (Lescuyer et al. 2010). It included questions on the sawyers' motivations, the targeted tree species, the use of the revenue earned from sawnwood, problems and potential solutions. The survey explores respondents' costs and profits from their latest chainsaw activities. Using this approach, we were able to estimate the amounts of parafiscal charges levied on sawyers for their last deliveries. However, it was not possible to obtain a precise estimate of the diameter of the felled trees: the millers only recognised 'big', 'medium' and 'small'. Sixty operations were investigated: 23 in the Brazzaville area and 37 around Pointe-Noire.

\section{Monitoring flows of chainsaw timber into Brazzaville}

Brazzaville has several timber markets, each with several outlets. At the beginning of the survey period (June 2008), the main markets were located in the following districts: Ouenzé (three markets), Bacongo (two markets) and Moungali (one market), with approximately 70 outlets in total.

Brazzaville receives timber by river (Ampolo and Bita 1996) and by road (Ampolo 2005). After monitoring a certain number of passage points for several weeks, the checkpoints at Djoué, Safelmi, the airport and the railway station were omitted from the survey because timber traffic was slow. Our survey was limited to four supply delivery points: the ATC port, Port Yoro, the (informal) landing at Tsiémé and the road through the Djiri checkpoint (Map 2).

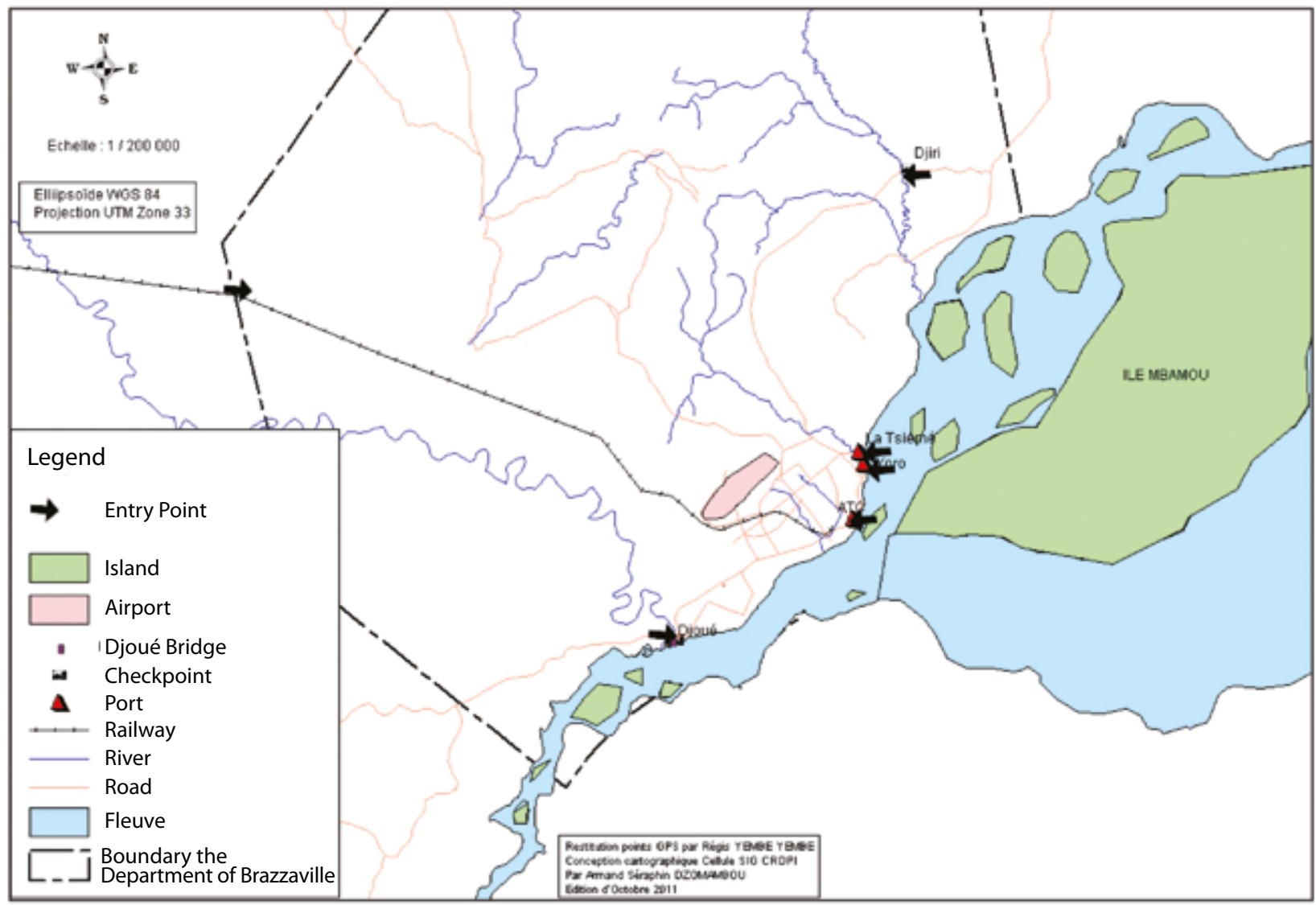

Map 2. Location of monitoring points for timber entering Brazzaville 
Because of the large number of outlets and the small number of access points, the survey team only monitored timber passing through these access points, rather than spreading out to cover a large number of sales points. At each access point, a standard form with items on the date, type of vehicle, size of delivery, product, species, origin and, if possible, the quality of the wood (sawmill scrap or chainsaw wood) was filled in regularly by the two interviewers, whose responses were checked at random by an external interviewer. The frequency of data collection for each access point is presented in Table 2. The ports are closed on Sunday.

On site, the interviewers collected data for a whole day of activities (24 hours). From June 2009, the interval between surveys was reduced so that the team could observe two days of activity per week on all the sites and so better assess differences in volumes of weekly timber deliveries. A full-time researcher was hired for the Tsiémé landing to monitor the complete flow of timber transiting through that access point. The choice of survey data gathered is important in order to avoid overestimating or underestimating the volumes when extrapolating the information to a full week. At the ATC and Yoro ports, the interviewer selected the survey day at random for the first period, and decided, for the second period, to be on site every Monday (high activity level) and Wednesday (low activity level) in order to cover the periods of high and low activity systematically. The survey days were selected at random for both periods on the Djiri road, and for the first period at the Tsiémé landing. Our survey at the Tsiémé landing had to be suspended from February to May 2009 because of difficulties with the army. To cover the whole year, we assumed that the weekly timber flows at the Tsiémé landing for this period were the same as the average volumes for the weeks covered in January and June 2009, that is, $99 \mathrm{~m}^{3}$ per week.

For the ATC and Yoro ports and the Djiri road, data were extrapolated to the weekly scale by multiplying by three the total volumes recorded by the survey team during their two days on site - this was a slightly 'cautious' extrapolation for the Djiri road, which is open seven days a week - in order to estimate the total volume of sawnwood passing through these access points during opening hours.

Because of the survey conditions, especially at night, it was not always possible to identify the quality of the products entering the city, that is, to distinguish between industrial scrap and chainsaw timber.

\section{Monitoring outlets in Pointe-Noire}

In Pointe-Noire, as in many cities in Central Africa, the chainsaw timber sales network is organised around specialised markets; each comprises at least five outlets, as found during a study conducted in May 2008 and August 2009 that systematically counted the markets and outlets throughout the city (Table 3, Map 3).

Eleven main timber markets were identified in Pointe-Noire and its outskirts. The number of markets did not change between May 2008 and August 2009, but the number of outlets in these markets doubled, which demonstrated the sector's vibrant reaction to the high (7.5\%) economic growth rate in 2009. Our survey sample, composed of 77 outlets, was monitored in 11 markets during a 15-month period, although our estimates were based on only 11 months. Most outlets are about $2 \mathrm{~m}$ wide, $7-8 \mathrm{~m}$ deep and $2.5 \mathrm{~m}$ high.

Table 2. Survey schedule in Brazzaville

\begin{tabular}{|c|c|c|c|c|}
\hline & The ATC port & Port Yoro & Tsiémé landing & Djiri road \\
\hline Open & 6 days/week & 6 days/week & 7 days/week & 7 days/week \\
\hline $1^{\text {st }}$ survey period & Aug. 08 - May 09 & Aug. 08 - May 09 & Oct. 08 - Jan. 09 & Aug. 08 - May 09 \\
\hline $\begin{array}{l}\text { Frequency of data collection } \\
\text { in } 1^{\text {st }} \text { period }\end{array}$ & Once a week & Once a week & Once a week & Once a week \\
\hline $2^{\text {nd }}$ survey period & June 09 - Nov. 09 & June 09 - Nov. 09 & June 09 - Nov. 09 & June 09 - Nov. 09 \\
\hline $\begin{array}{l}\text { Frequency of data collection } \\
\text { in } 2^{\text {nd }} \text { period }\end{array}$ & Twice a week & Twice a week & Daily & Twice a week \\
\hline
\end{tabular}


Table 3. Small-scale timber markets in Pointe-Noire

\begin{tabular}{llccc}
\hline Name of market & Arrondissement & $\begin{array}{c}\text { Number of } \\
\text { outlets } \\
\text { (May 2008) }\end{array}$ & $\begin{array}{c}\text { Number of } \\
\text { outlets } \\
\text { (Aug. 2009) }\end{array}$ & $\begin{array}{c}\text { Number } \\
\text { of outlets } \\
\text { monitored }\end{array}$ \\
\hline Grand Marché & No. 1, Lumumba & 29 & 62 & 10 \\
Marché Mayaka & No. 3, Tié-Tié & 13 & 20 & 8 \\
Marché de Ndaka soussou & No. 3, Tié-Tié & 12 & 26 & 8 \\
Marché du Fond Tié-Tié & No. 4, Loandjili & 5 & 13 & 4 \\
Marché Siafoumou & No. 4, Loandjili & 6 & 5 & 5 \\
Marché Faubourg & No. 4, Loandjili & 2 & 13 & 4 \\
Marché de Loandjili & No. 4, Loandjili & 16 & 6 & 2 \\
Marché du terminus Mont Kamba & 12 & 21 & 16 \\
Marché de Mpaka & No. 3, Tié-Tié & 15 & 34 & 7 \\
Marché Tié-Tié 30 mars & No. 3, Tié-Tié & 6 & 11 & 4 \\
Marché de Roy & No. 2, Mvoumvou & 127 & 247 & 77 \\
Total & & & & \\
\hline
\end{tabular}

Survey methods and frequencies were the same throughout the period: one day a week, each outlet in the survey filled in a form indicating the type of products sold, the timber species, the size and origin of the products, stocks, the day's deliveries and the number of pieces (by product type and specie) sold on that day and the selling prices. These estimates were extrapolated to cover all the business days per week - five days for the Grand Marché, six days for the other markets - and then extrapolated to apply to all the outlets in the city.

The initial data collection plan involved the interviewers going to each market once a week to review the preceding day's activities with each outlet manager.

After several months, we realised that the survey protocol was not resulting in reliable information - the average daily sales figures for the outlets in Pointe-Noire were far below the estimated figures for Yaoundé, Douala and Libreville (Cerutti and Lescuyer 2011, Lescuyer et al. 2011). It turned out that outlet managers were not providing accurate information, probably because of the difficulty in building trust between researchers and sellers. The protocol was revised in February 2009 and the outlet managers were taught how to fill in the survey forms themselves, supervised by an interviewer with regular contact. This approach was used for less than a year (until November
2009), and so only data collected between February and November 2009 were used to estimate timber consumption in Pointe-Noire.

Another problem was that the number of outlets in the Pointe-Noire markets changed during the survey period, raising the question of whether we should use the May 2008 figures (127 outlets) or the August 2009 figures (247 outlets) when extrapolating the data collected in the monitored outlets to all the outlets in Pointe-Noire. To avoid overestimating the number of outlets at the beginning in 2009 , we based our calculations on an average of 180 outlets for all of 2009 .

In addition to the outlets in the markets, there are several stand-alone outlets in Pointe-Noire, especially in the fast-growing districts. A survey conducted in May 2009 identified 72 standalone outlets, mainly in the districts of Ngoyo (24 outlets), Tié-Tié (20 outlets) and Loandjili (18 outlets). A data collection protocol, identical to the one used for the market outlets, was employed between June and November 2009 in three outlets in Ngoyo to estimate the volumes of timber sold by these outlets throughout the district. To extrapolate sales correctly to the whole year, information was sought directly from the sellers, who explained that consumption was $50 \%$ lower during the rainy season (January-June 2009). 


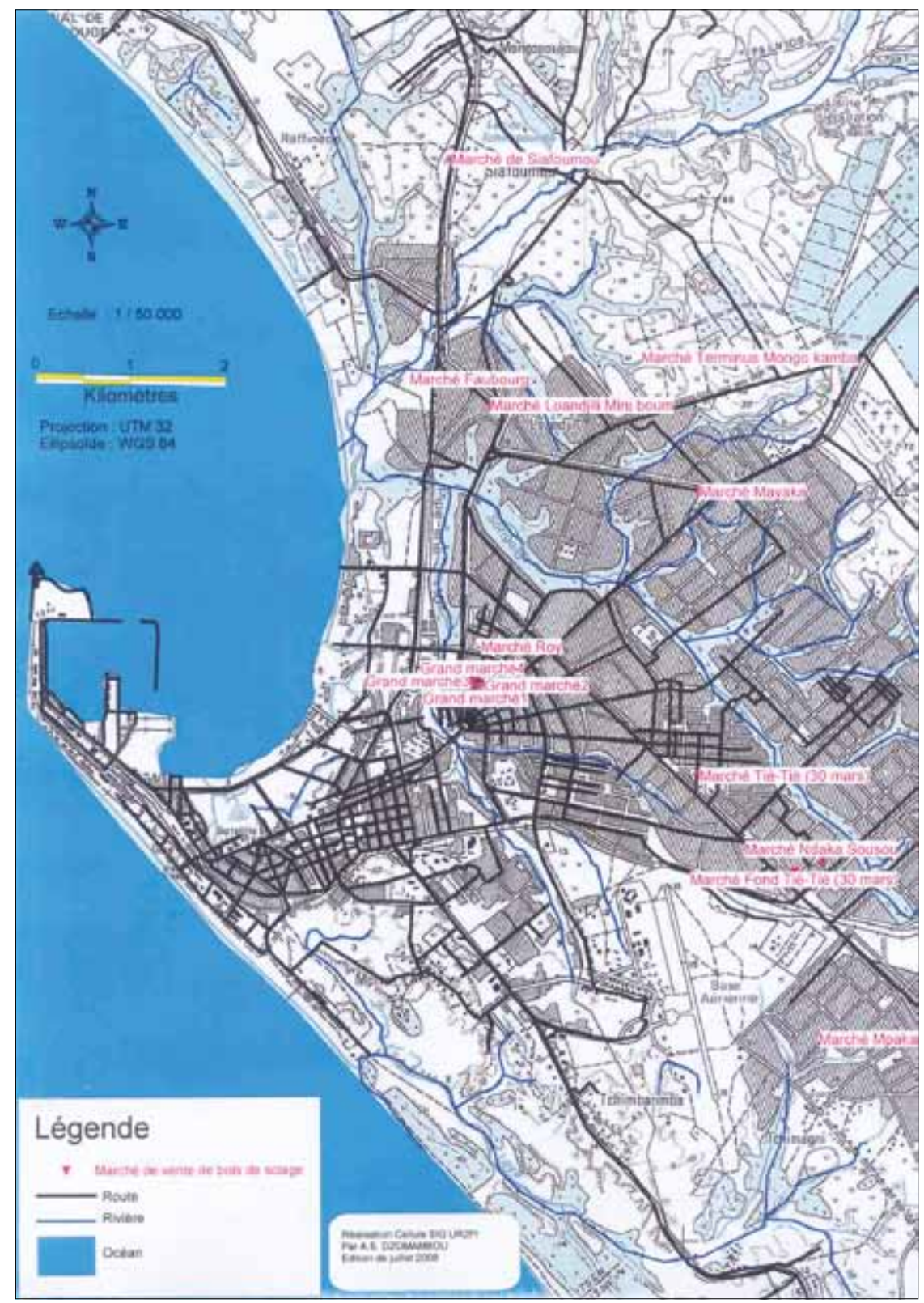

Map 3. Location of small-scale timber markets in Pointe-Noire 



\section{Results}

\section{Upstream: Economic importance of the chainsaw timber sector in rural areas}

\section{Developments and problems}

During recent decades, many people have learned to use felling equipment, a trend facilitated by the introduction of chainsaws into rural areas, where most people use them to produce lumber for housing construction. Small-scale chainsaw milling in Congo is an old profession, and the most experienced sawyers still working now started their careers in the 1980s. The sector became increasingly successful in both cities in the 1990s, although not at the same pace (Figure 1). Many Congolese in Pointe-Noire migrated to the south of the country between 1997 and 1999 because of the civil war.
Since 2005, the number of sawyers has increased greatly, mainly because of the economic growth of the city. In Brazzaville, chainsaw milling resumed after the war had ended.

Also noteworthy is that many of the sawyers in each zone come from outside that zone. Out of the 62 sawyers/machine operators in the survey, 32 came from a place other than their present place of work; for example, 13 respondents in the PointeNoire area who have been living in Kouilou for several years were born and raised in another part of the country. Furthermore, $15 \%$ of the sawyers in the sample were from the Democratic Republic of Congo. All the respondents said that their main reason for entering the profession was to earn money. Those who had to leave their hometowns

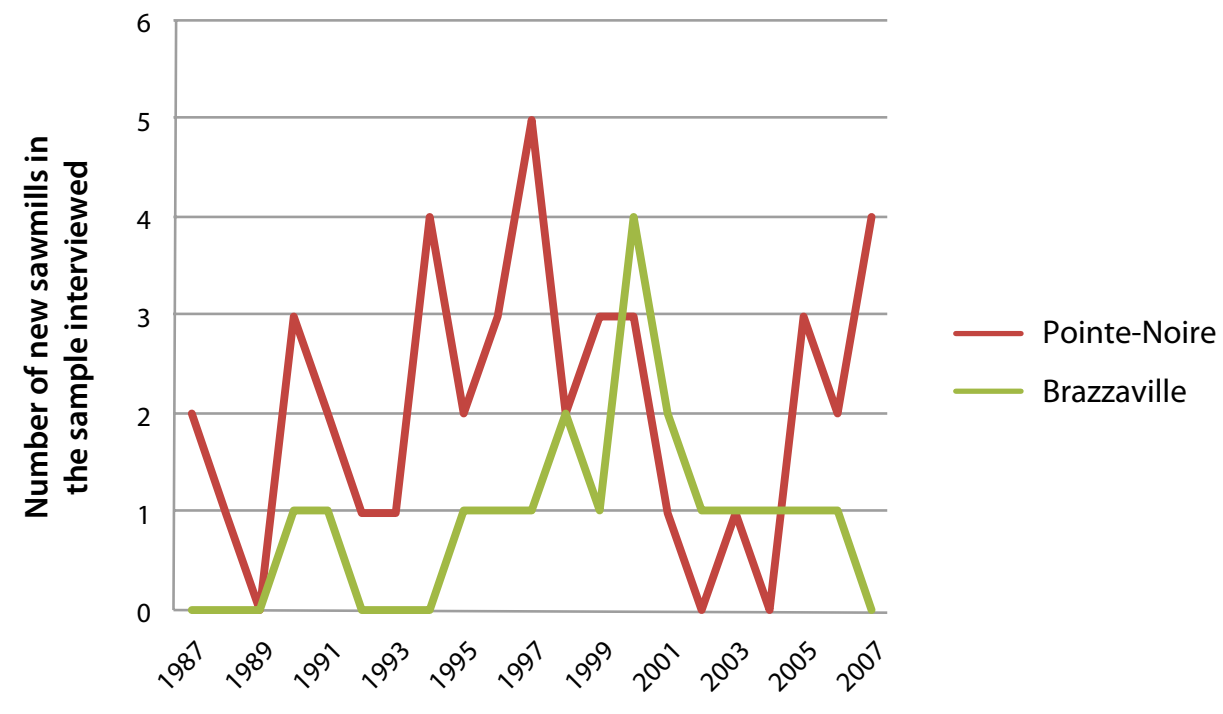

Figure 1. Years when the 62 surveyed chainsaw millers entered the profession 
in the 1990s probably viewed chainsaw milling as a job that could accelerate their economic integration in areas where access to land ownership and cultural integration would not be easy.

The main aim of working as a chainsaw miller is to earn enough to meet domestic needs. Survey respondents said that although the work is profitable, profits are rarely sufficient to enable them to make larger investments such as buying a vehicle or building a house. For example, only 18 (29\%) of the 62 sawyers in the survey own their own chainsaw. Most rent a chainsaw from other sawyers at a daily rate - the sawyer renting the chainsaw has to pay for repairs - or are provided with a chainsaw by their worksite supervisors (chef du chantier).

Only two (3\%) of the 62 respondents had any sort of logging permit at the time of the survey, confirming the predominance of the informal system. As a result, chainsaw millers have to deal with endless 'administrative hassles', which is the most commonly cited problem with their work (Table 4).

Chainsaws breakdowns were also a common problem Chainsaws often break down, probably because of old age - in our sample, the average chainsaw was over 10 years old and there were very few new ones - and the poor quality of the spare parts.

Table 4. Chainsaw millers' perceptions of problems encountered in their work (multiple choice)

\begin{tabular}{lc}
\hline Problems & Response rate (\%) \\
\hline Administrative hassles & 90 \\
Equipment breakdown & 55 \\
Transport & 20 \\
Fuel/lubricants supply & 11 \\
Employer-employee relations & 5 \\
Job drudgery & 5 \\
Bad weather & 3 \\
\hline
\end{tabular}

\section{Profitability}

Data in the questionnaires completed by the respondents were useful in describing the costs of the 60 forestry operations monitored in the two survey zones between June 2008 and October 2009. The timber products and prices were recorded, providing the data needed to estimate the upstream side of the industry, that is, from felling to the sale of products to urban clients and traders.

Chainsaw milling involves a range of operations, with the following costs.

Tree purchases from traditional owners. Trees are felled in areas under state control but where customary land ownership rights - through clan, lineage or family - grant local populations access to the land. Hence, any customary owner, from clan chief to head of family, can legally claim ownership of trees and/or woodlands and thus can sell 'his' trees to a sawyer. Customary ownership allows for legal exploitation of natural resources, but only for personal use. Selling trees to sawyers who supply the domestic market may be illegal, but it is common practice and is accepted in Congo, as well as in the other countries in the Congo Basin. (Cerutti and Lescuyer 2011, Lescuyer et al. 2011). The respondents did not mention disputes with customary owners as a major problem (Table 4).

Felling the tree and cutting it into lumber. After a transaction with the customary owner has been completed, a team is set up to identify the trees, cut them down and saw them into pieces. This production chain has not changed in the 15 years since it was described by Ampolo and Bita (1996). The felling team is usually composed of four to six people who have a chainsaw and other equipment such as a gruminette (Photo 1), a special saw commonly found in Congo (Pasiecznik 2010). On the team are (1) an independent sawyer, who usually works with his relatives; or (2) a worksite supervisor (chef de chantier), who works under the protection and instructions of an urban employer. These employers recruit workers in the felling zone or in the city and deal with the village leaders personally. The operating methods and cost structure are much the same in both cases, although parafiscal charges tend to be lower for the second type of team because the chef de chantier 


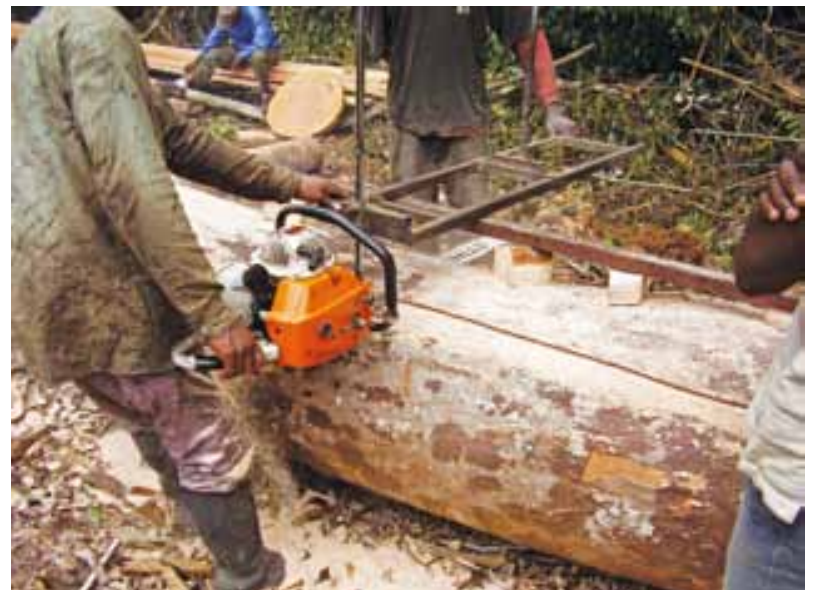

Figure 2. A gruminette for small-scale sawing (Photo by Régis Is-maël Yembe-Yembe)

can ask his employer in the city to lay pressure on the checkpoints along the way and thereby reduce the amount of 'hassle'.

Transport to the evacuation point. Porters then lug the sawn timber to an access road or a river for it to be loaded on to a vehicle. A team may have from two to five porters, depending on the distance and the volume of the sawn timber. Porters are nearly always young men from the nearest village.

Transport to the nearest city (in this study, Pointe-Noire or Brazzaville). To cut costs, the sawn timber is often transported alongside other goods on a truck or timber wagon. Whatever the means of transport, an informal transport tax has to be paid. State agents - the Water and Forests Team, the gendarmerie, the police or the 'ecoguard' - charge set (but negotiable) amounts for any vehicle transporting timber produced in the informal sector. They refer to Circular No. 896 of
22 July 2002, which prohibits the sale of products from the informal chainsaw milling sector outside the felling area (Ondele-Kanga 2011). Receipt of payment is seldom provided. The same situation was observed by ADEMA (2009) in the area around the Dimonika biosphere reserve near Dolisie.

Urban sales of sawn timber. Nearly everything is sold within the city, rather than at the processing site (this was also observed by Ampolo (2005)). The sawyer must therefore pay for the transportation, a cost that he adds to his selling price. Upon arrival in the city, the sawyer either delivers an order $(62 \%$ of the cases studied) or looks for a buyer (38\% of the cases studied). There are several types of buyers for chainsaw timber (companies, individuals, etc.) but $69 \%$ of the transactions we observed were with wholesale buyers, who then sell the products to wood outlets or sell them in their own retail outlets.

Using information on expenses and profits from these operations -23 around Brazzaville, 37 around Pointe-Noire - we could estimate the financial profitability of this activity in the Brazzaville and Pointe-Noire supply basins (Table 5).

Small-scale chainsaw milling is generally profitable in Congo, even though the average profit margin seems lower than in earlier estimates; for example, for Brazzaville alone, Ampolo and Bita (1996) estimated profits at $37000 \mathrm{CFA}$ Francs $/ \mathrm{m}^{3}$ in 1995 while Ampolo (2005) lowered this estimate to somewhere between 13500 and $21000 \mathrm{CFA}$ Francs $/ \mathrm{m}^{3}$ in 2005. Our estimate of the average profit margin, around 14500 CFA Francs per cubic metre, is comparable to the profit margin calculated

Table 5. Profits and costs for chainsaw timber in rural areas (CFA FRANCS $/ \mathrm{m}^{3}$ of sawnwood)

\begin{tabular}{lrcrrrr}
\hline Description & Average & $\boldsymbol{\sigma}$ & Brazzaville & $\boldsymbol{\sigma}$ & Pointe-Noire & $\boldsymbol{\sigma}$ \\
Payment to owner & 2986 & 2095 & 3727 & 2381 & 2526 & 1779 \\
Local wages & 30148 & 14368 & 45140 & 10905 & 20829 & 5729 \\
Equipment and fuel & 6510 & 3140 & 6833 & 3158 & 6309 & 3156 \\
'Taxes' & 11792 & 8145 & 11053 & 9910 & 12252 & 6940 \\
Transport to market & 13462 & 9921 & 17610 & 10825 & 10883 & 8478 \\
Total costs & $\mathbf{6 4 8 9 9}$ & & $\mathbf{8 4 3 6 3}$ & & $\mathbf{5 2 7 9 9}$ & \\
Sales price to seller & 79322 & 31252 & 92361 & 19005 & 71217 & 34697 \\
Profit & 14423 & & 7998 & & 18418 & \\
\hline
\end{tabular}


recently for Cameroon and Gabon (Cerutti and Lescuyer 2011, Lescuyer et al. 2011).

The difference in costs and sales prices for wood between Brazzaville and Pointe-Noire is largely due to the wood species selected by the smallscale millers: 'red woods' in Brazzaville (bossé, mahogany, wengue, etc.) and 'white woods' in Pointe-Noire (especially okoumé). Production costs are higher for red woods because of the higher price of the standing trees with their precious wood, the felling and sawing time (which means paying more wages) and transport, but the selling price is high. For white woods around Pointe-Noire, the final selling price is lower but the even lower total costs mean that profit margins are considerably higher.

The wage structure also explains the difference in profit margins. Around Pointe-Noire, wages are based on a standard price per cubic metre of sawnwood produced or transported; however, as fewer sawyers work for the Brazzaville market, they are in a better position to negotiate their wages, and hence are paid more per piece.

The breakdown of the cost price for a cubic metre of sawnwood until the first sale is made shows two important factors characterising the upstream side of this sector (Figure 3). First, payments to customary owners and local wages total about 33000 CFA Francs for each cubic metre of sawn timber produced. This money is injected into the rural economy. As in other countries in the sub-region, more than half the cost price for this activity goes directly into the local economy, although part of the wages go to the chef de chantier and his assistant, who do not live in the felling zone. This timber production method, calculated per cubic metre, therefore has major financial implications for rural populations. Second, although the Forestry Code stipulates that the sawyers and the village residents must agree on financial specifications and conditions if the state is to issue a permit, the sawyers' payments to the customary owners are negligible.

The other main beneficiaries in this sector are the representatives of the state agencies who are posted along the timber transportation routes. Their 'parafiscal' levies amount to about $18 \%$ of the price paid for timber in the cities. These levies constitute the main problem for the chainsaw millers and are a major element in the poor governance of the decentralised public services. The political, administrative and military elite are all party to these illicit dealings (Ondele-Kanga 2011).

\section{Ecological impacts}

Several factors observed during the survey suggest that small-scale chainsaw milling may have an impact on the forest ecosystem (Table 6).

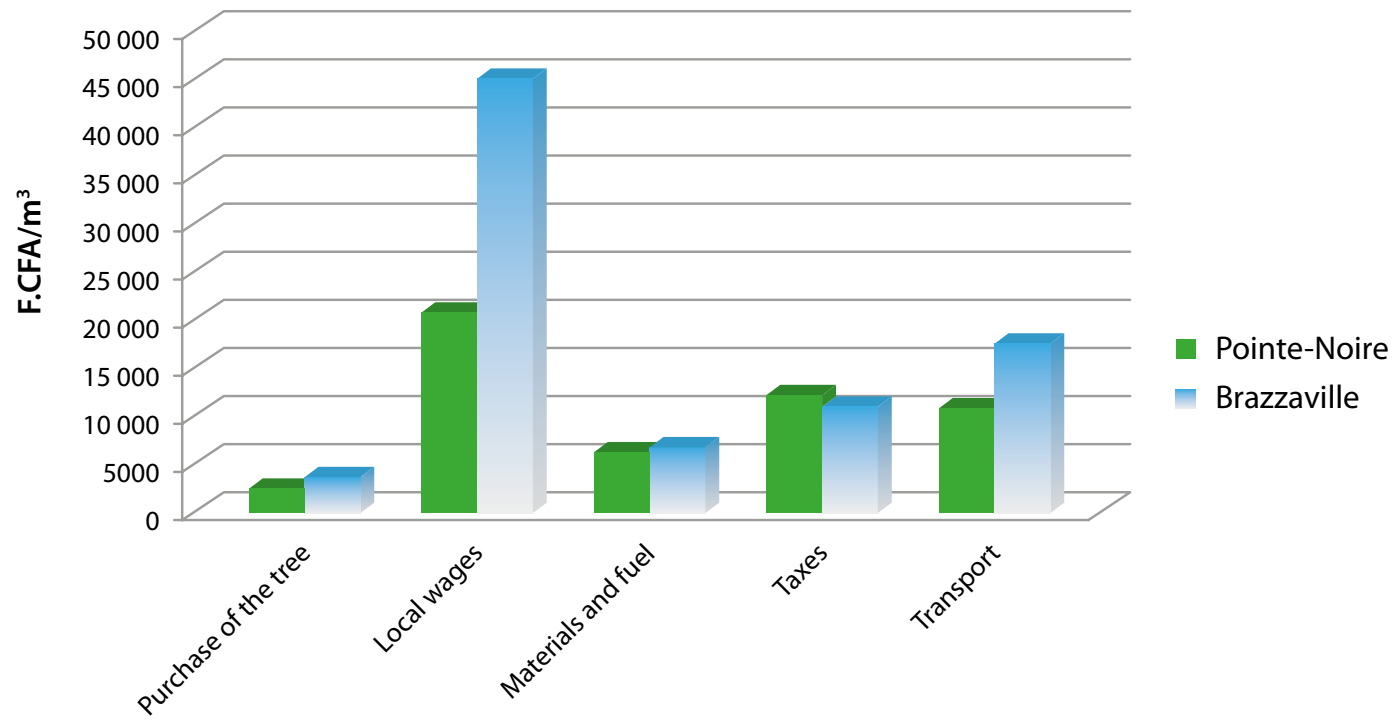

Figure 3. Breakdown of expenses for small-scale timber production in rural areas 
Table 6. Intensity and location of small-scale chainsaw milling operations

\begin{tabular}{|c|c|c|c|}
\hline & Average & Brazzaville & Pointe-Noire \\
\hline Number of trees felled per'felling site'a & $11.1(\sigma=7.23)$ & $5.7(\sigma=4.23)$ & $14.4(\sigma=6.73)$ \\
\hline Main species sought & & $\begin{array}{l}\text { longhi (Gambeya } \\
\text { spp.), bossé (Guarea } \\
\text { cedrata), dibetou (Lovoa } \\
\text { trichilioides) }\end{array}$ & $\begin{array}{l}\text { okoumé, baya (Hallea } \\
\text { ciliata) }\end{array}$ \\
\hline Walking distance from felling site & $4.2 \mathrm{~km}(\sigma=2.05)$ & $3.4 \mathrm{~km}(\sigma=1.00)$ & $4.7 \mathrm{~km}(\sigma=2.37)$ \\
\hline $\begin{array}{l}\text { Volume of sawn timber produced per } \\
\text { tree felled }\end{array}$ & $0.52 \mathrm{~m}^{3}(\sigma=0.30)$ & $0.31 \mathrm{~m}^{3}(\sigma=0.10)$ & $\left.0.7 \mathrm{~m}^{3}(\sigma=0.31)\right)$ \\
\hline
\end{tabular}

a 'Felling site' refers to the area used by the chainsaw millers to produce a commercially worthwhile volume of sawnwood, usually around $15 \mathrm{~m}^{3}$, which is the volume that can be transported in a forestry truck. The felling site may be small if the sawyer comes across a grove with large numbers of saleable species, but more often than not, the trees are scattered, meaning that the sawyer has to cut down, say, three trees here, one over there and two more farther away, to obtain the target volume.

Chainsaw milling at both study sites is characterised by low productivity, with a sawnwood volume per tree well under volumes estimated in the neighbouring countries. Consequently, sawyers must fell a large number of trees in order to produce a commercially worthwhile amount. To find enough trees, the sawyers must trek long distances; the more trees needed, the greater the distance to be trekked.

These sawyers tend to exploit secondary forests (63\% of our sample), particularly around PointeNoire, and gallery forests (37\% of our sample) around Brazzaville, in ecosystems that usually do not have large numbers of large, commercially attractive tree species. Ampolo (2005) noted that the trees felled around Brazzaville were all smaller than the minimum cutting diameter for authorised felling. The combination of sources in the ecosystem, the number of trees felled in each operation and the low processing rates suggest that sawyers often fell trees with a small diameter, sometimes merely $40 \mathrm{~cm}$. This raises the question of the ecological sustainability of this system.

\section{Consumption of chainsaw timber in Brazzaville}

During the past 10 years, forestry enterprises in northern Congo have been transporting most of their output by road through Cameroon to the Port of Douala, thereby reducing the use of river transport to supply the domestic market (Ampolo and Bita 1996). However, two companies recently decided to open furniture stores in Brazzaville, transport to which involves road and river: (1) by road from the Batéké Plateau and (2) by river from the gallery forests near Brazzaville for chainsaw timber and from factories in the north for certain substandard sawnwood.

We monitored sawnwood shipments through the main road and river passage points into Brazzaville for 69 weeks, except for the Tsiémé landing, where the survey started late and was intermittently suspended because of problems with the army. We used the data collected to calculate the total annual volume of sawnwood that enters Brazzaville to supply the domestic market, which we estimated at around $34500 \mathrm{~m}^{3}$ per year for 2008 and 2009. This is much more than the $7300 \mathrm{~m}^{3}$ of timber that reached Brazzaville by river 15 years ago, according to calculations by Ampolo and Bita (1996). Given that Brazzaville has no primary processing plant for wood that could supply urban markets directly, the city's domestic consumption of sawnwood is supplied from these outside sources.

Sawnwood deliveries in Brazzaville seem to follow a two-phase pattern, as shown in Figure 4, which plots the weekly volumes of sawnwood entering through four access points. There is a slack period between October and March when the average weekly volume is less than $600 \mathrm{~m}^{3}$, and a peak period between April and September with peaks of more than $1600 \mathrm{~m}^{3}$ of sawnwood entering Brazzaville each week. This pattern was observed in 2008 and 2009; the main explanation is the amount of rainfall during the wet season. 


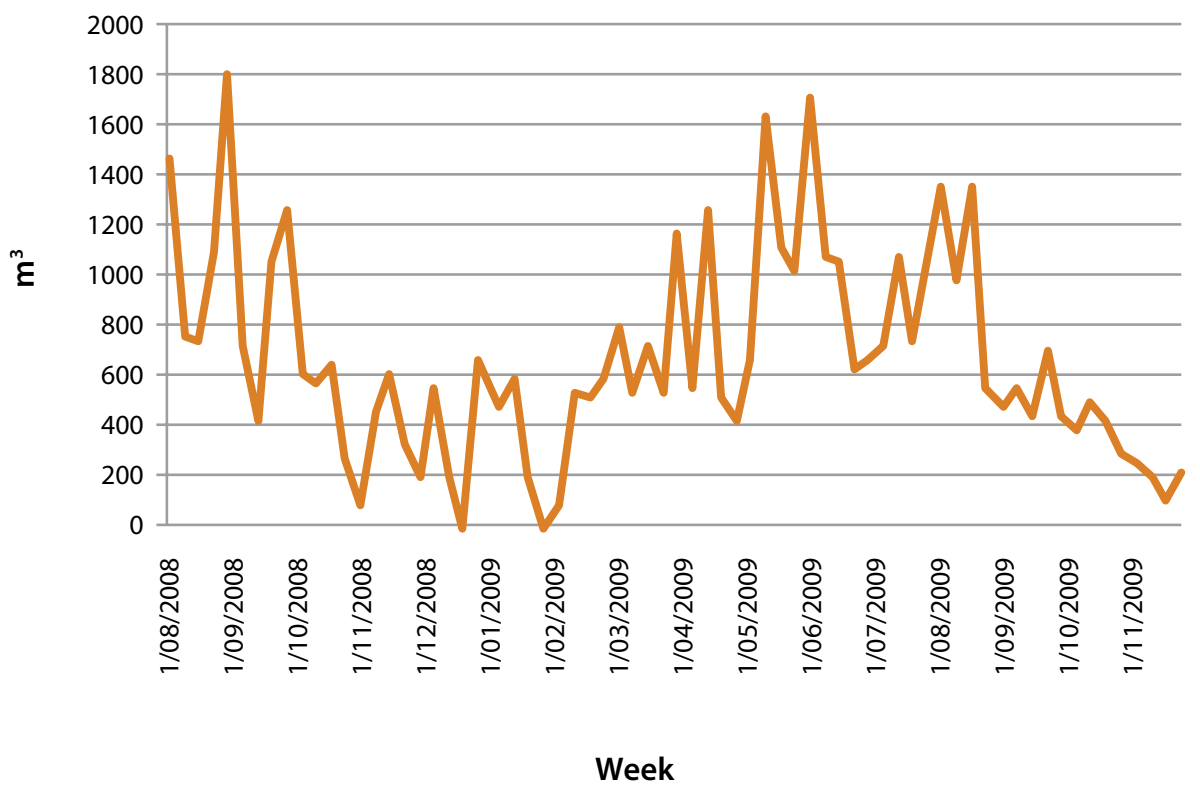

Figure 4. Estimates of weekly sales of sawnwood in Brazzaville

The ATC port handles $49 \%$ (i.e. $17000 \mathrm{~m}^{3}$ ) of the shipments of sawnwood into Brazzaville (Figure 5). The sawnwood comes from Betou (42\%), Mossaka (26\%) and Enyélé (20\%).

Operators generally prefer river transport for two reasons: first, certain forests, particularly in the north of the country, can only be reached by water, and second, there are fewer - and more relaxed - checkpoints on the river than on the roads to Brazzaville.

About $7600 \mathrm{~m}^{3}$ per year is transported by road. The main production zone for road transport is located at Ollombo ( $40 \%$ of the transport vehicles), followed by Ngo (26\%) and Ebou and Ekono (15\% each). None of these zones can supply Brazzaville legally because the relevant special permits only authorise timber sales within the administrative department (département) where the permit was issued. ${ }^{2}$

The Tsiémé and Yoro ports each handle about $5000 \mathrm{~m}^{3}$ per year, shipped from zones that are similar to each other, mainly Ngabé, Ngobila, Ouesso and Bokaba.

2 Eight special permits were issued in Ngo in 2009, for instance.
Slightly more red wood (sapelli, moabi, sipo, etc.) is transported to Brazzaville than white wood (ayous, longhi, etc.): $18500 \mathrm{~m}^{3} /$ year and $16000 \mathrm{~m}^{3} /$ year, respectively (Figure 5). Long planks of $6 \mathrm{~m}$ make up almost half of the total volume of white wood shipments but only one-third of the red wood shipments. Chevrons (half red wood, half white wood) are second in terms of annual volume of sawnwood entering Brazzaville. Scantlings, on the other hand, are usually made of red wood (twice the volume of white wood). The proportions of timber products suggest that the construction sector is the biggest consumer of sawnwood

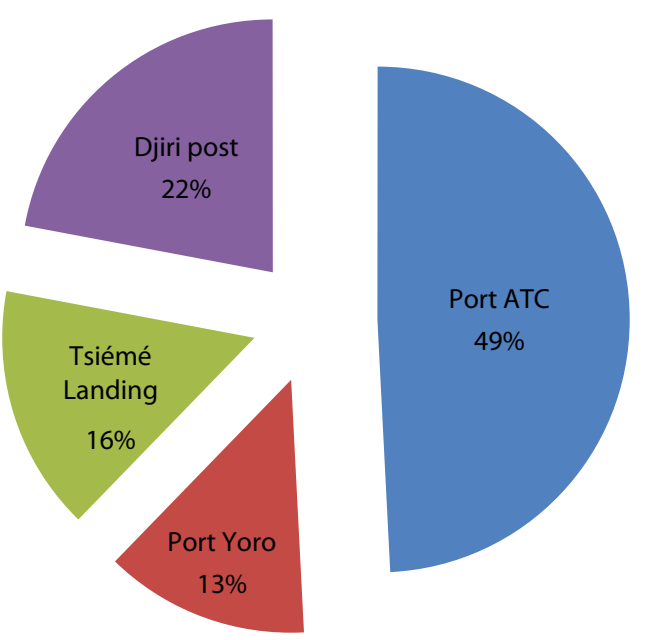

Figure 5. Sawnwood deliveries to Brazzaville, per entry point 


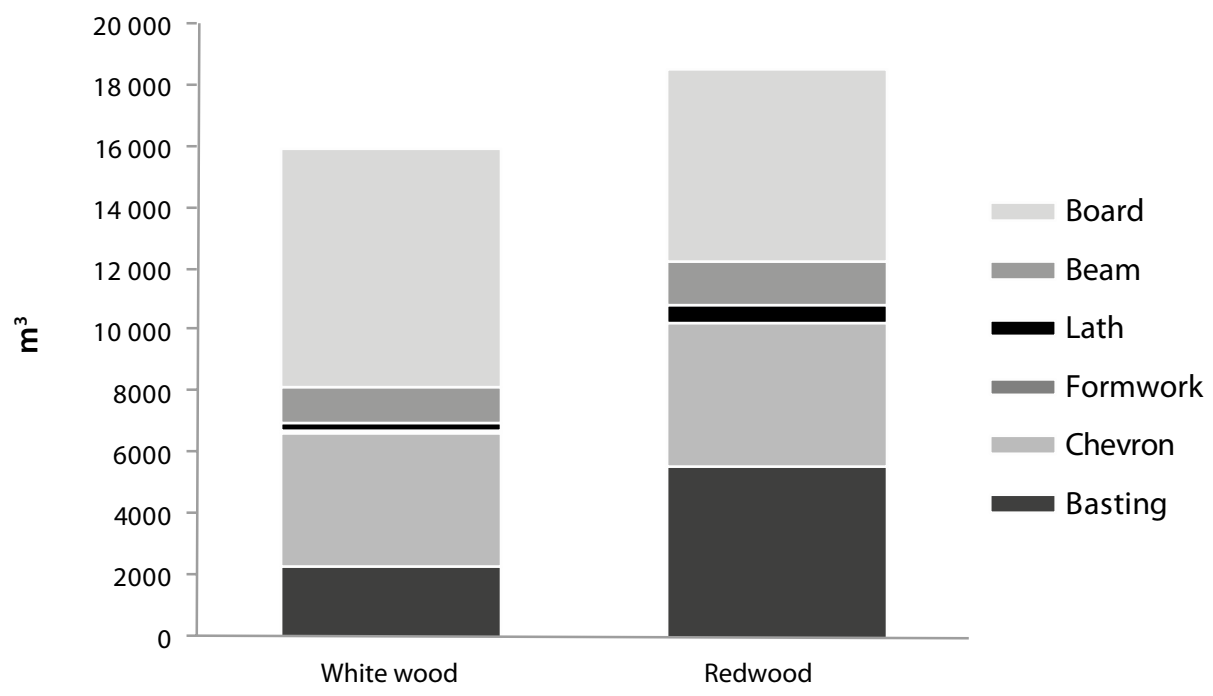

Figure 6. Types of timber products entering Brazzaville

products, as Ampolo and Bita (1996) observed 15 years ago.

\section{Sales and consumption of chainsaw products in Pointe-Noire}

As in most cities in Central Africa, trade in small-scale chainsaw products in Pointe-Noire is organised around sales outlets that are either grouped in the market or spread out across the city, especially in the outskirts. There is a logic to this bimodal geographic breakdown: the market outlets offer more services, large volumes and a wide range of products, whereas those in the outskirts are closer to urban buyers who, for instance, build their houses in outlying areas where land prices are more affordable.

The number of outlets that sell chainsaw timber in the 11 markets in Pointe-Noire grew from 127 to 246 between May 2008 and August 2009 (Table 3). The detailed survey of a sample of 77 outlets helps to explain the following socio-economic characteristics of this sector in urban areas.

Jobs. On average, each outlet employs just over two individuals, including 1.3 as permanent employees and 0.7 as temporary employees. Through extrapolation to all the outlets in the city, the labour force can be estimated at about 410 permanent jobs and 230 temporary jobs. In addition to jobs attached directly to the outlets, there are several, informal 'small jobs' related to timber sales, such as the sales promoters who serve as brokers and the sorters who unload and sort the wood. There are no statistics about these specialised workers, although they constitute a sizeable group.

Ownership, age and gender. In $57 \%$ of the cases, the outlet manager and owner are one and the same. The average age of outlet managers is 37 years. Only $8 \%$ of the managers are women, and almost all of them own their outlet, as was also noted by Fabing (2004).

Wages. The mode of payment depends on the outlet - by piece, day or month - but the salary is generally 30000 CFA Francs/month. In terms of permanent jobs, the sale of chainsaw timber generates a total payroll of about 150 million CFA Francs per year in Pointe-Noire; adding temporary jobs brings the total to 200 million CFA Francs. ${ }^{3}$

Supplies. In addition to the many passable roads to Pointe-Noire, the railway is another important means for transporting informal sector timber into Pointe-Noire, especially from the Mayombe forests (ADEMA 2009). The chainsaw timber is loaded in villages where trains stop and unloaded at unscheduled night stops somewhere between

3 These estimates include the wages that the employer-cumseller would pay if he were to pay himself at the market rate. 
Ngondi and Tié-Tié stations for onward transport to outlets in the city centre. Some outlets, such as the Nouvelle Trabec company, obtain wood directly from the sawmills located in Pointe-Noire.

The activities of the 77 outlets in the sample and the three stand-alone outlets in the Ngoyo district were monitored constantly from February to November 2009. Extrapolated to all outlets in the city, this information was used to estimate the volume of chainsaw timber products sold in Pointe-Noire at $71000 \mathrm{~m}^{3}$ for this period, which gives an average amount of about $98000 \mathrm{~m}^{3}$ per year. Nearly all sales (93\%) are made at the markets. The outlets located in the markets sell, on average, $1.40 \mathrm{~m}^{3}(\sigma=1.05)$ per day, or twice as much as the stand-alone outlets in the Ngoyo district, which have average daily sales of about $0.77 \mathrm{~m}^{3}(\sigma=0.43)$.

The volume of chainsaw timber sold does not fully correspond to the volume of informal sector timber consumed in Pointe-Noire, for the following three reasons.

- Part of the timber may come from districts around Pointe-Noire covered by the special permit. However, in 2009, the forestry services did not issue any special permits because insufficient forest area was available for smallscale chainsaw operations.

- Sawmill products are among the sawnwood. We estimated that only three of the six products monitored in our sample outlets might be derived from processing plants: lathes $(13.7 \%$ of the total volume of sales), chevrons (1.6\%) and scantlings $(0.6 \%)$. Altogether, approximately $2000 \mathrm{~m}^{3}$ of these sawmill products is sold in the outlets in Pointe-Noire. Fabing (2004) and more recently Giostra (2011) estimated the volume of sawnwood from industrial plants entering the local market in southern Congo at about $10000 \mathrm{~m}^{3}$ per year, which means that the bulk of these products is sold directly at the sawmills, without ever reaching the market.

- Some of this sawnwood is sold from one outlet to another, especially in the Grand Marché, when certain outlets run out of stock. These 'double sales' account for $15 \%$ to $45 \%$ of the total weekly volumes of sales.

- After sawmill products and double sales are subtracted from the global volumes of sawnwood sales, the sawnwood from the informal sector consumed in Pointe-Noire is estimated at $73000 \mathrm{~m}^{3}$ per year - three times the amount estimated for 2002 by Fabing (2004). The output of chainsaw timber is hence double that of the formal sector in southern Congo, which Giostra (2011) estimated at about $34000 \mathrm{~m}^{3}$ in 2010 .

The consumption of chainsaw timber is relatively even throughout the year, with a peak in May when more construction work is being prepared for the dry season, which begins in June (Figure 6).

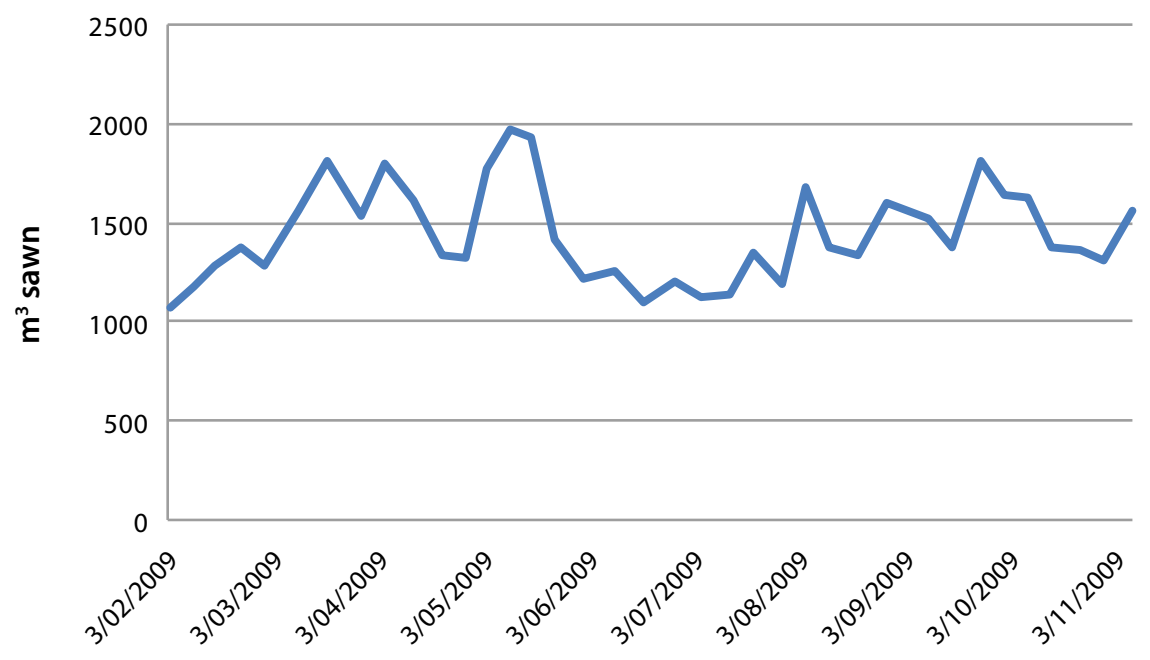

Figure 7. Estimate of weekly consumption of sawnwood in Pointe-Noire 
Sawnwood sells in the city at a price two to three times higher than that paid to the sawyers. The selling price ranges from 125000 CFA Francs per cubic metre for formwork in white wood to 240000 CFA Francs for large scantlings made of 'heavy wood'. Prices recorded by Fabing (2004) for 2002 were lower, between 110000 CFA Francs and 185000 CFA Francs per cubic metre. The increase is probably due to growing urban demand and the relative scarcity of the products.

The products sold in Pointe-Noire are the same as those sold in Brazzaville, except for 'milomba', a rough wooden plank cut by axe, which PointeNoire residents use to build their houses; moreover, the production site is close by.

The markets in the two cities differ in terms of the trade value of the various products. In Brazzaville, wooden planks are the leading product, with about $14000 \mathrm{~m}^{3}$ sold per year, compared with $9000 \mathrm{~m}^{3}$ a year in Pointe-Noire (Figure 7). This difference is attributable in part to the higher prices for scantlings and chevrons. For the Brazzaville consumer, it is less expensive to buy the planks and have them cut into smaller pieces by the circular-saw operators (déligneuses) located in the city than to buy these products at the market.
In both cities, however, there is strong demand for chevrons and scantlings because of their many uses in construction, furniture and minor repairs, among others.

Another explanation for the different consumer preferences in Pointe-Noire and in Brazzaville is related to the location of the tree species that are prized on the urban markets (E. Forni personal communication). Pointe-Noire consumers prefer products made of white wood - from trees found in the south of the country, whereas Brazzaville customers prefer hard woods, found in the northern region.

Nine tree species provide $57 \%$ of the volumes of chainsaw timber sold in Pointe-Noire although in varying proportions, depending on the type of product: niové (Staudtia stipitata), for instance, is used mainly for scantlings and planks. Okoumé is preferred for formwork and lathes. Milomba is produced mainly from species such as water ilomba (Pycnanthus marchalianus) that grow in humid zones. Of all the species and products, okoumé is the most attractive for sawyers, who produced over $12000 \mathrm{~m}^{3}$ of okoumé sawnwood for outlets in Pointe-Noire in 2009.

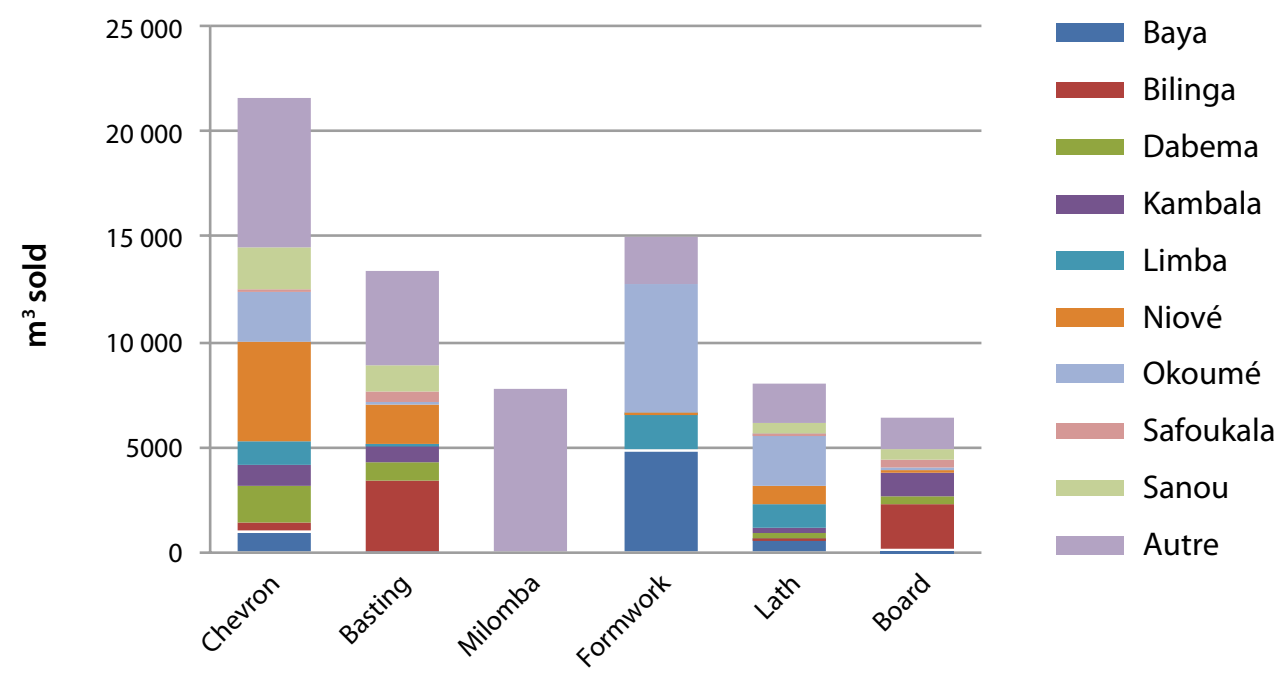

Figure 8. Types of sawn products and species exploited around Pointe-Noire 



\section{Discussion and conclusion}

$I^{\prime}$ $\mathrm{n}$ the Republic of Congo, as in the other countries in the sub-region, little effort has been made to study the domestic chainsaw milling sector. The results in this report provide data with which to assess the socio-economic importance of this sector and suggest ways to make it more formal. However, revisions and amendments of regulations will have little effect unless accompanied by serious changes in governance, which will require the introduction of a system of incentives to change practices by state agents.

\section{Macro-economic importance of small- scale chainsaw milling sector}

Recent reports on Congolese forestry policy indicate that sustainable forest management will depend on the effective implementation of a standard model for forest concessions supported by a forest management plan. Such a model should be effective in zones with small or sparse human settlements, but not in forestlands located near cities and under pressure to supply the urban market. As domestic demand for timber is largely ignored by the industrial sector, even in the centre and the south of the country where the main cities are located, most small-scale milling has stayed in the informal economy.

In Brazzaville, three of the four passage points for sawnwood receive timber produced exclusively within the informal sector, either because the (very few) permits that have been issued do not cover this trade, or because the goods pass these points at night and these points are located in unsafe

Table 7. Annual volumes of chainsaw timber in the Republic of Congo

\begin{tabular}{|c|c|c|}
\hline Annual estimate (2009) & Brazzaville $\left(\mathrm{m}^{3}\right)$ & Pointe-Noire $\left(\mathrm{m}^{3}\right)$ \\
\hline Annual volume of sawnwood entering the city: & 34500 & \\
\hline - industrial products (half via ATC port) & 8500 & \\
\hline - timber from the informal sector & 26000 & \\
\hline Annual volume of sawnwood sold in the city: & & 98000 \\
\hline - 'double sales' & & 23000 \\
\hline - industrial products & & 2000 \\
\hline - informal sector sawnwood & & 73000 \\
\hline Total annual volume from informal sawmill sector (2009) & \multicolumn{2}{|c|}{99000} \\
\hline Volume of exports from industrial sawmills (2009) & \multicolumn{2}{|c|}{93000} \\
\hline Volume of exports from industrial sawmills (2008) & \multicolumn{2}{|c|}{175000} \\
\hline Volume of exports from industrial sawmills (2007) & \multicolumn{2}{|c|}{209000} \\
\hline
\end{tabular}


areas. The situation is more complex for the ATC port, which also receives sawnwood downgraded by the sawmills in the north, as indicated by the geographical origin of the wood. The northern sawmills are supposed to prioritise local markets and, until recently, have not made much effort to supply adequate volumes to the distant Brazzaville market. It is therefore unlikely that the downgraded wood from the sawmills in the north accounts for more than $50 \%$ of the timber required in Brazzaville - our hypothesis on flows that transit through the ATC port.

In Pointe-Noire, where no special permits have been issued, the greatest amount of the sawnwood purchased comes from informal sources, because the industrial sawmills meet only a small part of the city's needs.

The total consumption of sawnwood from informal sources in 2009 for both Pointe-Noire and Brazzaville was close to $99000 \mathrm{~m}^{3}$ (Table 7), which is more than the volume (approx. $93000 \mathrm{~m}^{3}$ ) of industrial sawnwood products exported from Congo the same year.

The informal timber sector competes directly with the formal sector in working to meet urban demand. To enhance the competitiveness of the formal sector in the domestic market, the 2009 Finance Law introduced a zero-tax rate on added value for sawn products. Although this has helped reduce the gap between the two sectors, it is not enough to effect fundamental change, mainly because the industrial sector does not have sufficient capacity to meet domestic demand.

Although the populations of Pointe-Noire and Brazzaville are about the same size, timber consumption is much higher in Pointe-Noire, probably because the forests are closer and the city is enjoying faster economic growth than Brazzaville. The increase in the number of outlets for wood in Pointe-Noire during our survey period is indicative of this trend. Another factor is the difference in building techniques: in Brazzaville the scaffolding and props are often made of steel, at least in the city centre, while in Pointe-Noire use of wood is more common.
The estimated combined sales value of sawnwood from the informal sector in Pointe-Noire and Brazzaville in 2009 was about 15 billion CFA Francs. This amount is calculated based on a volume of $99000 \mathrm{~m}^{3}$ multiplied by the average estimated retail price of about $150000 \mathrm{CFA}$ Francs $/ \mathrm{m}^{3}$ (about double the average price paid to sawyers). By comparison, according to the Food and Agriculture Organization of the UN, the value of industrial sawnwood exports in 2009 totalled about 23 billion CFA Francs.

The informal sector generates jobs in both urban and rural areas. As mentioned above, chainsaw milling has created about 410 permanent jobs and 230 temporary jobs in Pointe-Noire. Although similar statistics are not available for Brazzaville, Ampolo and Bita (1996) mentioned the existence of over 70 small-scale 'sawmills'. In all likelihood, the situation has evolved favourably in the 15 years since then, and more than 200 people now have regular jobs in this sector in Brazzaville. For the two cities combined, therefore, over 600 permanent jobs and at least 300 temporary jobs exist in chainsaw milling sales and processing operations. Further, this sector supports, almost singlehandedly, various labour-intensive subsectors such as carpentry and cabinet-making.

It is much more difficult to determine the number of jobs connected to small-scale milling in rural areas because workers are highly mobile and participate irregularly. A macro estimate could, perhaps, be made based on the following three variables: (1) $100000 \mathrm{~m}^{3}$ of sawnwood is produced each year; (2) the average yield of a milling team is $1 \mathrm{~m}^{3} /$ day (Ampolo 2005, Cerutti and Lescuyer 2011); and (3) a team is composed, on average, of six individuals. Under these assumptions, smallscale chainsaw milling can be credited with creating an estimated 2000 full-time jobs in the rural zones that supply Brazzaville and Pointe-Noire. Actually, however, this sector involves a much larger number of people at the national level because, on the one hand, it affects many zones that are not covered in our sample and, on the other, it generates many secondary jobs, such as transporters and brokers, that are not factored into these estimates. 
Chainsaw timber is affordable for urban households and businesses. The timber trade therefore not only contributes to the economic development of urban areas, but also plays an important role in rural economies where much of the production costs (i.e. wages and payments to customary owners) are spent in the villages. Drawing on our estimates of volumes and production costs, we estimate that about 1.3 billion CFA Francs per year reaches the rural households that participate in the milling sector in areas that supply timber from the informal sector to Brazzaville. With financial benefits exceeding 1.7 billion CFA Francs per year in the area around Pointe-Noire, chainsaw milling is highly profitable for rural populations, although it does create challenges for forestland sustainability. At least in the immediate and medium-term future, however, chainsaw milling is likely to increase the revenue of a large number of rural households and thus contribute to the development of these poverty-stricken areas.

The implementation of the VPA will affect the informal sector. However, given the volume of business and the involvement of a very large part of the Congolese population, the VPA will not cause the downfall of this sector in the short or medium term. The elimination of chainsaw milling would significantly lower the standard of living in areas engaged in this profession if the unearned income is not replaced by some other form of livelihood. The system for redistributing part of the forest taxes, which is not very efficient in other countries in the sub-region, is not working at all in Congo. One of the challenges for the legalisation process will be convincing chainsaw millers to obtain a legal felling permit - a procedure intended to contribute both to sustainable forest management and to the state coffers - without changing their current, labour-intensive production methods. Facilitating contractual arrangements between small-scale sawyers and industrial companies to exploit valuable species is one idea worth exploring. Similarly, industry could sell the legal sawyer the plants' lower-grade logs at their reference price (valeur mercuriale). Whatever solutions are to be tested, the present regulations will have to be revised and adapted.

\section{Rethinking the regulations}

The small-scale milling sector is supported by the customary tenure system for forest land and resources, at least in the NPFE. Traditional owners have the power to grant access to land and make a handsome profit from it, although user rights are not valid for commercial felling. Another problem with current practices is the risk they pose to environmental sustainability, for instance in the areas around Pointe-Noire. Both the state and informal operators feel that legalising the profession would be the best way to ensure sustainability and improve the efficiency of timber production, but that such a decision should not jeopardise the interests of the local populations, especially of customary owners, as well as the more recently arrived village dwellers and indigenous populations, which are often left out.

In both the Brazzaville and Pointe-Noire supply zones, the small number - or complete absence - of special permits is evidence of the difficulties in enforcing the present regulations. As Ampolo (2005) pointed out, the legal framework and regulations on forestry management in Congo do not provide for large business transactions based on small-scale milling operations. The special permit, which was introduced as a tool for supervising small-scale operations, is not designed for such a large domestic timber market. It has three major drawbacks that discourage small-scale sawyers from legalising their work.

\section{Procedural red tape and related costs. Even} sawyers who have all the required documents must wait several weeks before the forestry services approve the request for a special permit. Official response times are seldom respected. The reams of documents required, the relative complexity of the official procedures and the ill-equipped government services make the procedure costly for the applicants, who, moreover, nearly always have to pay the state forestry agent's travel costs if they want their application to be processed without inordinate delays. According to Ampolo (2005), for the zones around Brazzaville, each sawyer had to have a special permit, which cost about 400000 CFA Francs. Very few sawyers can pay that high a price merely for a legal permit. 
Scope and time. The investment in time and money required to obtain a special permit is disproportionate to the monthly allotment of five trees that the permit holder is authorised to fell. Indeed, the few sawyers who do have a special permit use it for much longer than it is valid for and largely exceed their quota, thus lapsing into illegality.

Geographical coverage. Restricting the sale of timber felled under a special permit to the administrative department in which it was felled prevents the sawyers from supplying a city such as Brazzaville, which does not have its own sawmill or any major forest nearby.

These regulations trap the individual sawyers in an illegal situation because the legal conditions for small-scale operations are beyond their reach. Unless the present regulations on chainsaw milling are substantially revised, the introduction of the VPA could worsen the situation. Along with a very short-term permit enabling the sawyers to meet local demand, such as the special permit, a felling permit for larger volumes of timber and authorisation to sell on the national market should be considered. This is a prerequisite for supplying legal timber to the main consumer centres.

Some regional offices of the Ministry of Forest Economy are aware of this bottleneck and have introduced adaptive measures that are not fully in step with the law. Some small-scale operators, for instance, have been issued riders to their official permits to cover a zone where they could fell and process a certain number of trees, especially if they used portable chainsaws. The regional offices control timber production operations in these areas. To facilitate small-scale milling that satisfies real economic needs, the government forestry services in other countries such as Gabon (Lescuyer et al. 2011) have sometimes introduced similar 'para-formal' measures, although these do not fully comply with national regulations.

Another legal source of supply for the domestic sawnwood markets could be created by establishing community development areas within the forest management units. Under such a system, the local population would be allowed to fell trees and earn money legally if the method of forest exploitation follows a management plan approved by the government forestry services (Ministry of Forest Economy 2007). It would be rather easy to issue special permits for commercial trade in these zones and to control their application, by working in collaboration with the concession holders and the resident populations. Before the VPA can be enforced in community development areas, the forest regulations would have to be revised to include this option.

The Ministry of Forest Economy is keen to promote forestland development, but this option is not compatible with the growing number of small-scale timber production sites. A land-based solution to the problem of permits would be to create a smallscale permit (permis artisanal) that authorises exploitation of a certain volume in the NPFE located in a vast area such as an administrative department. The creation of this type of milling permit would also provide an opportunity to increase the role of rural populations in accepting and monitoring legalised small-scale milling operations.

Whatever the types of permit available, the legalisation of small-scale production operations is likely to boost prices for sawnwood on the national market. The present price for sawnwood is based on a felling method that mines the forests given that, according to field observations and the study by Ampolo (2005), the diameter of many of the felled trees is under the minimum authorised size. A legal chainsaw production operation would only be allowed to fell trees with a larger diameter - that is, trees that are located further from the urban markets. This would affect the cost of transportation and, ultimately, the selling price on the urban market.

Several support measures could be used to compensate for these price increases, at least in part, such as a differentiated tax system in which the tax rate would be proportionate to the distance from the felling site, as introduced by the Gabonese government for the industrial sector, or the professionalisation of sawyers to enable them to maintain their profit margins. Other complementary possibilities include 
technical training to improve the processing rate, professional associations, access to credit and outsourcing to forest enterprises.

Any regulatory change must be accompanied by a convincing reduction in parafiscal levies imposed by officials, who could be expected to apply them to a newly legalised informal timber sector. This could be achieved by an incentives mechanism to persuade such official actors to accept the reforms.

\section{Incentives to improve governance}

Although necessary, regulatory change will not be sufficient to formalise this sector. People working in the sector must feel that they will gain personal benefits from the formalisation process. Two groups of actors are directly concerned: chainsaw millers and decentralised government agents. Much of their income comes from informal chainsaw milling and some would prefer the present system to continue. Nevertheless, many millers would like to become legal, if only to avoid 'hassles'.

The strongest incentive for individual sawyers to support the legalisation of their trade would be a guaranteed reduction in parafiscal charges, without any 'over-compensation' through a high admission price to enter the legal sector. Most sawyers would be keen to apply for a legal permit if it did not mean higher operating costs. However, merely formalising the small-scale logging sector would not necessarily reduce parafiscal charges but, on the opposite, can contribute to increase production costs without generating significant gains.

The Congolese forestry services do not usually check industrial timber permits very efficiently (Mertens et al. 2007, Cerutti et al. 2010). However, there are many decentralised government agents who carefully monitor the evolution of the informal milling sector, although not to the benefit of the state. In some cases, government agents - or the like, such as the ecoguards - run a regular racket in the informal sector, levying charges but never delivering receipts. This money serves as personal income for those government officials who tacitly accept informal chainsaw milling, despite being tasked with preventing it. According to our estimates of informal timber sales and rates charged per cubic metre by government services installed along the road, parafiscal income totals close to 290 million CFA Francs per year for the Brazzaville area and almost 900 million CFA Francs per year for the Pointe-Noire area. ${ }^{4}$ Were small-scale chainsaw milling to become legal in Congo, how could these officials be convinced to abandon their criminal practices - which are highly profitable for themselves - to enforce regulations that would first and foremost benefit the state?

The solution generally recommended is tighter control of state agents and strict punishments for embezzlement. This approach should be encouraged but may be insufficient, considering the present amounts of income generated by parafiscal charges. It would therefore advisable to combine penalties with incentives. A payments mechanism could be created, based on the performance of the government services responsible for promoting and implementing the regulations. At the department level, such a mechanism could entail paying a bonus that would be proportionate to the number of small-scale felling permits issued, applied and controlled. The ultimate goal would be to replace private income from an informal activity with an official bonus pegged to the operationalisation of a legal logging entity. Although not easy to implement, this type of mechanism is essential to achieve improvements in the governance of this sector. However, it could encourage considerable abuse, for example by encouraging services that are currently not very involved in parafiscal taxation to lobby to become eligible for the legalisation bonus at a later time. A proposed mechanism could be tested in certain major departments. Pilot tests are particularly necessary in this context because informal chainsaw milling, as now practised - large numbers of trees felled, sawyers' low productivity - is unarguably detrimental to the forest. The contribution of chainsaw milling to the well-being of the rural population and the national economy will only become sustainable if the sawyers change their ways - a change dependent on the design and enforcement of regulations.

4 These estimates do not include possible levies on urban outlet owners. 



\section{References}

ADEMA 2009 Exploitation artisanale du bois dans la réserve de biosphère de Dimonika (Kouilou, République du Congo). Internal report. Association pour le Développement du Mayombe, Brazzaville, Republic of Congo.

Ampolo, A.N. 2005 La transformation artisanale des bois tropicaux: cas des scieries artisanales au Congo Brazzaville. Dissertation, École nationale du génie rural, des eaux et des forêts (ENGREF).

Ampolo, A.N. and Bita, A.C. 1996 Le sciage artisanal du bois et la commercialisation des débités à Brazzaville. Wildlife Conservation Society, Nouabalé-Ndoki Project.

Barbier, C. 2004 Désertification et forêts. SILVA, Nogent-sur-Marne, France.

Bayol, N. and Eba'a Atyi, R. 2009 Les forêts de la République du Congo en 2008. In: de Wasseige, C., Devers, D., de Marken, P., Eba’a Atyi, R., Nasi, R., Mayaux, P. (Eds.), Les forêts du Bassin du Congo: état des forêts 2008, pp 101-114. Observatory for the Forests of Central Africa and Congo Basin Forests Partnership, Brussels.

Cerutti, P.O. and Lescuyer, G. 2011 The domestic market for small-scale chainsaw milling in Cameroon: present situation, opportunities and challenges. Occasional Paper 59. Center for International Forestry Research (CIFOR), Bogor, Indonesia.

Cerutti, P.O., Schmitt, A. and Moukouri, S. 2010 Le parcours des données forestières en République du Congo. L'exemple de la taxe d'abattage. Forests Monitor and Resource Extraction Monitoring, Brazzaville, Republic of Congo.

European Forestry Institute (EFI) 2010 Voluntary Partnership Agreement FLEGT between the Republic of Congo and the European
Union. Briefing note. Delegation of the European Union to Congo and Ministère du développement durable, de l'économie forestière et de l'environnement, Brazzaville, Republic of Congo.

Fabing, A. 2004 Dynamique du secteur informel et des petites entreprises au sein de la filière bois dans la région sud du Congo. Centre de coopération internationale en recherche agronomique pour le développement (CIRAD), Montpellier, France.

Giostra, D. 2011 État sur l'industrialisation du secteur bois au sud Congo. Presentation at the IFIA-ITTO-FAO conference: Vers une stratégie de développement de l'industrie de transformation de bois dans le bassin du Congo: défis et perspectives pour la république du Congo. Brazzaville, Republic of Congo 22-23 March.

Lescuyer, G., Cerutti, P.O., Essiane Mendoula, E., Eba'a Atyi, R. and Nasi, R. 2010 Chainsaw milling in the Congo Basin. European Tropical Forest Research Network (ETFRN) News 52: 121-128.

Lescuyer, G., Cerutti, P.O., Ndotit, S. and Bilogo Bi Ndong, L. 2011 The domestic market for smallscale chainsaw milling in Libreville (Gabon): present situation, opportunities and challenges. Occasional Paper 63, Center for International Forestry Research (CIFOR), Bogor, Indonesia.

Maldonado, C. and Gaufryau, B. 2001 Léconomie informelle en Afrique francophone. Structure dynamiques et politiques. International Labor Office, Geneva.

Mertens, B., Minnemeyer, S., Nsoyuni, L.A. and Steil, M. 2007 Atlas forestier interactif du Congo. Synthesis report. World Resources 
Institute and Global Forest Watch, Washington D.C.

Ministry of Forest Economy 2007 Arrêté n ${ }^{\circ}$ 5053/ $\mathrm{MEF} / \mathrm{CAB}$ définissant les directives nationales d’aménagement durable dans les concessions forestières. 19 June 2007. Brazzaville, Republic of Congo.

Ngouari, A., 2005 Economie informelle et pratiques populaires au Congo Brazzaville: état des lieux et perspectives. Université du Québec en Outaouais.

Nkoua, M., Besse, F., Matondo, R. and Hervé, G. 2009 Approvisionnement en produits ligneux d'usage local de la ville de Pointe-Noire: rapport d'enquête flux du 13 au 26 juin 2006. Internal report. UR2PI, Pointe-Noire, Republic of Congo.

Ondele-Kanga, A. 2011 Alternatives pour finaliser le secteur informel. Presentation at the IFIA-ITTO-FAO conference: Vers une stratégie de développement de l'industrie de transformation de bois dans le bassin du Congo: défis et perspectives pour la république du Congo. Brazzaville, Republic of Congo, 22-23 March.

Pasiecznik, N. 2010 Sawmilling with chainsaws: a technical overview. European Tropical Forest Research Network (ETFRN) News 52: 3-12. 

CIFOR Occasional Papers contain research results that are significant to tropical forestry. The content is peer reviewed internally and externally.

In 2000, the Republic of Congo adopted a new forestry law that emphasised export-oriented, large-scale industrial forestry. Timber from small-scale logging operations for the domestic market were ignored, not recorded in official statistics and generally produced without a valid permit. Congo in 2009 initialled and in 2010 signed a Voluntary Partnership Agreement (VPA) with the European Commission, promising a legal framework for all national timber production by 2013. Preparations for the implementation of the VPA are well underway for the forest concessions, especially in the northern part of the country, but the domestic timber sector has been largely ignored in this process. This report presents a quantitative and qualitative evaluation of the country's domestic timber market as a step towards identifying options for legalising the market and ensuring its sustainability. 